\title{
Benthic foraminifera from the deep-water Niger delta (gulf of Guinea): Assessing present-day and past activity of hydrate pockmarks
}

\author{
C. Fontanier ${ }^{a, b, ~}{ }^{*}$, K.A. Koho ${ }^{c, d}$, M.S. Goñi-Urriza ${ }^{e}$, B. Deflandre ${ }^{f}$, S. Galaup ${ }^{g}$, A. Ivanovsky ${ }^{a}$, b, c, d, e, f, g, h \\ N Gayet ${ }^{h}$, B. Dennielou ${ }^{a}$, A. Grémare ${ }^{f}$, S. Bichon ${ }^{f}$, C. Gassie ${ }^{e}$, P. Anschutz ${ }^{f}$, R. Duran ${ }^{e}$, G.J. Reichart ${ }^{d}$
}

\author{
a IFREMER, Laboratoire Environnements sédimentaires, Centre de Brest, Technopôle de Brest-Iroise, BP 70, F- \\ 29280 Plouzané, France \\ ${ }^{\mathrm{b}}$ Université de Nantes/Angers/Le Mans, CNRS, LPG UMR 6112, BP 92208, F-44322 Nantes Cedex 3, France \\ ${ }^{c}$ Department of Earth Sciences - Geochemistry, Faculty of Geosciences, Utrecht University P.O. Box 80.021, \\ 3508 TA Utrecht, The Netherlands \\ ${ }^{d}$ Royal Netherlands Institute for Sea Research, Landsdiep 4, 1797 SZ „t Horntje, The Netherlands \\ e Université de Pau et des Pays de l'Adour, CNRS, IPREM 5254 - Equipe Environnement et Microbiologie, BP \\ 1155, F-64013 Pau Cedex, France \\ ${ }^{f}$ Université de Bordeaux, CNRS, Environnements et Paléo-environnements Océaniques et Continentaux, UMR \\ 5805, F-33400 Talence, France \\ ${ }^{\mathrm{g}}$ Ecole d'ingénieurs en Environnement, Géoressources et Ingénierie du Développement durable, IPB-ENSEGID, \\ F-33607 Pessac Cedex, France \\ ${ }^{h}$ IFREMER, Laboratoire Environnements Profonds, Centre de Brest, Technopôle de Brest-Iroise, BP 70, F-29280 \\ Plouzané, France
}

\section{*: Corresponding author : C. Fontanier, tel.: +33621919348 ; email address : $\underline{\text { Christophe.Fontanier@ifremer.fr }}$}

\begin{abstract}
:
We present ecological and isotopic $\left(\delta^{18} \mathrm{O}\right.$ and $\left.\delta^{13} \mathrm{C}\right)$ data on benthic foraminifera sampled from 4 deepsea stations in a pockmark field from the deep-water Niger delta (Gulf of Guinea, Equatorial Atlantic Ocean). In addition, a series of sedimentological and (bio)geochemical data are shown to back up foraminiferal observations. All stations are located within $1.2 \mathrm{~km}$ of each other, so prevailing oceanographic conditions can be assumed to be similar at each site. Two of the sites (GMMC-01 and GMMC-02) are located in a pockmark (named "pockmark A") where current methane seepages were recorded by ROV observations. A third station (GMMC-03) is located in the topographic depression interpreted as a collapsed pockmark (named "pockmark B"). The fourth site (GMMC-04) is a reference station, without evidence of past or present seepages. Our observations show that degraded organic matter with low bio-availability is present at all stations with a preferential burial of organic compounds in topographic depressions (GMMC-03 station). Authigenic aragonite is abundant in surface sediments at stations GMMC-01 and -02. Its precipitation is likely related to high rates of methane oxidation during past seep events in episodically active pockmark A. In contrast, the absence of anaerobic methanotrophic Archaea (ANME) during the sampling period (November 2011) suggests that only moderate sulphide and methane oxidation take place close to the sediment-water interface. Compared to the reference site GMMC-04, living foraminifera at the collapsed and episodically active pockmarks show minor changes in terms of diversity, standing stocks and faunal composition. However, the $\delta^{13} \mathrm{C}$
\end{abstract}


signal of living and dead (but well-preserved) foraminiferal species (Ceratobulimina contraria, Melonis barleeanus, Uvigerina peregrina) is depleted in the episodically active pockmark A compared to the other stations. Overgrowth of authigenic carbonate on altered foraminifera generates an important shift to lower $\delta^{13} \mathrm{C}$ values. Dead faunas carry a complex time-averaged message, integrating taphonomic gains and losses related to the temporal variability of gas emission. They reveal major faunal differences that may be useful to detect gas hydrate seepages in different pockmark stages.

\section{Highlights}

We work on living and dead benthic foraminifera sampled in a pockmark field. Fossilizing meiobenthos are compared between seep and non-seep sites. The $\delta^{13} \mathrm{C}$ signatures of living faunas are depleted in episodically active pockmark. In dead faunas, dominant opportunistic species indicate episodic seepage events.

Keywords : Niger Delta ; Hydrate pockmark ; Foraminifera ; Stable Isotopes ; Bacteria

\section{Introduction}

Hydrocarbon seeps on continental margins provide interesting settings for investigating the biogeochemical functioning and biodiversity of extreme deep-sea benthic environments and also for industrial exploitation of hydrocarbon resources. In these areas, methane and hydrogen sulphide trickle out of sediments through the seabed into the overlaying water. In sediments below the seafloor, these fluid seepages sustain a succession of biogeochemical redox reactions (e.g., Campbell, 2006). At the sediment-water interface, hydrogen sulphide and methane that have escaped oxidation in deeper sediments can sustain chemosynthetic communities, including endemic benthic metazoans (e.g., vesicomyid and mytilid bivalves or siboglinid tubeworms) that thrive with mutual endosymbiotic prokaryotes (mainly sulphuroxidizing bacteria) (e.g., Sibuet and Olu, 1998; Sahling et al., 2002; Levin and Mendoza, 2007). Differences in sulphide and methane fluxes in the uppermost sediment lead to the development of a specialized biozonation of chemoautotrophic prokaryotes and a patchy distribution of benthic eukaryotes (e.g., Sibuet and Olu, 1998; Sahling et al., 2002; Foucher et al., 2009).

Living benthic foraminifera (Eukaryota, Rhizaria) from modern cold seeps have been investigated in number of studies (e.g. Akimoto et al, 1994; Sen Gupta and Aharon, 1994; Kitazato, 1996; Sen Gupta et al., 1997, 2007; Rathburn et al., 2000, 2003; Bernhard et al., 
2001; Torres et al., 2003; Martin et al., 2004; Heinz et al., 2005; Panieri, 2006; Mackensen et al., 2006; Lobegeier and Sen Gupta, 2008; Bernhard et al., 2010; Martin et al., 2010). The previous work suggests that foraminiferal species observed in cold seep areas are not endemic/exotic and may be recruited from adjacent non-seep zones (e.g., Sen Gupta and Aharon, 1994; Kitazato, 1996; Sen Gupta et al., 1997; Rathburn et al., 2000, 2003; Lobegeier and Sen Gupta, 2008; Martin et al., 2010). Metabolic adaptations (facultative anaerobic metabolism, mutualism with prokaryotes), habitat and food preference (elevated epibiotic habitat, bacteriovore) might explain foraminiferal occurrence in methane- and sulphideenriched sediments (e.g., Bernhard et al., 2001; Panieri, 2006; Mackensen et al., 2006; Sen Gupta et al., 2007; Lobegeier and Sen Gupta, 2008; Bernhard et al. 2010). Additionally, stable isotopes $\left(\delta^{13} \mathrm{C}, \delta^{18} \mathrm{O}\right)$ in foraminiferal tests have been studied in present and past cold seep environments (e.g., Sen Gupta and Aharon, 1994; Rathburn et al, 2000, 2003; Torres et al., 2003, 2010; Martin et al., 2004; Hill et al., 2004; Mackensen et al., 2006; Wiedicke and Weiss, 2006; Martin et al., 2010; Bernhard et al., 2010; Hayward et al., 2011; Panieri et al., 2012). The geochemistry of pore water may be strongly influenced by methane-rich fluid seepage (e.g., Teichert et al., 2005; Rongemaille et al., 2011). The $\delta^{13} \mathrm{C}$ signatures of thermogenic and biogenic methane are generally lower than $-35 \%$ and isotopically-light methane oxidation in the Sulphate-Methane Transition Zone (SMTZ) results in pore water that is enriched in light dissolved inorganic carbon (e.g., Rathburn et al., 2003; Martin et al., 2007). Therefore, the $\delta^{13} \mathrm{C}_{\mathrm{DIC}}\left(\delta^{13}\right.$ of dissolved inorganic carbon) of pore water may shift relatively rapidly from very depleted $\delta^{13} \mathrm{C}$ to heavier bottom-water signatures according to (1) either diffusive or advective flows of methane-rich fluid toward the sediment-water interface, (2) efficiency of methane oxidation in a potential SMTZ, and (3) all biogeochemical processes influencing the budget of stable carbon isotopes in upper sediments (e.g., organic matter mineralisation) (e.g., Rathburn et al., 2003; Martin et al., 2010). The $\delta^{13} \mathrm{C}$ values in 
(living) foraminiferal tests show the influence of methane-enriched fluid, with a clear shift to lower values compared to adjacent non-seep areas (Sen Gupta and Aharon, 1994; Rathburn et al., 2000, 2003; Torres et al., 2003; Mackensen et al., 2006, Martin et al., 2010). However, in some studies strong disequilibrium has not been noted between the $\delta^{13} \mathrm{C}$ of living foraminiferal tests from cold seep zones and the expected very low $\delta^{13} \mathrm{C}_{\mathrm{DIC}}$ of hydrate-gas fluid (e.g., Sen Gupta et al., 1994; Torres et al., 2003; Bernard et al., 2010). Therefore, it has been suggested that foraminifera may calcify during periods low methane discharge or during intermittent episodes of seawater flow into sediments (Torres et al., 2003). In addition, foraminiferal $\delta^{13} \mathrm{C}$ signatures may also reflect the ${ }^{13} \mathrm{C}$-depleted food source (e.g. methanotroph bacterial biomass) and/or prokaryotic symbionts (Sen Gupta and Aharon, 1994; Rathburn et al., 2003; Panieri, 2006; Mackensen et al., 2006; Bernhard et al., 2010). Accordingly, Panieri (2006) documented lighter protoplasmic $\delta^{13} \mathrm{C}$ for foraminifera living in hydrocarbon seeps compared to an adjacent non-seep area, suggesting that Beggiatoa (prokaryotes) may be a food source for the foraminifera. In contrast to living data, strong $\delta^{13} \mathrm{C}$ depletion is recorded in fossil foraminifera. This may be related to diagenetic effects including post-mortem authigenic carbonate overgrowth and/or recrystallization in highalkalinity pore water around the SMTZ (e.g., Torres et al., 2003; 2010; Barbieri and Panieri, 2004; Wiedicke and Weiss, 2006, Panieri et al., 2009). Thus, previous work implies that the $\delta^{13} \mathrm{C}$ of dead foraminifera might be unreliable for building an accurate chronology of seep activity throughout centuries and millennia.

Along the prominent deep-water Niger delta (Gulf of Guinea, Equatorial Atlantic Ocean), various studies have documented different sea-floor sedimentary features such as pockmarks, mud volcanoes, gas hydrates and carbonate build-ups associated with cold seeps (e.g., Damuth, 1994; Brooks et al., 2000; Sultan et al., 2007, 2010, 2014; Bayon et al., 2007, 2011; Ruffine et al., 2013). Despite those numerous geochemical and sedimentological 
observations, fossilising benthic foraminifera have never been studied in this area. In this paper, an ecological and isotopic dataset of benthic foraminifera (living and dead) is presented and their potential proxy value of cold seep activity is assessed. In more detail, the aims of the study are: (1) to examine and compare living foraminiferal communities at stations experiencing current methane seepage and no seepage, (2) to compare dead benthic foraminiferal assemblages to the living ones and (3) to define whether seepage activity is recorded in the foraminiferal tests by an analysis of stable isotopes $\left(\delta^{13} \mathrm{C}, \delta^{18} \mathrm{O}\right)$ in living and dead foraminifera.

\section{Study area}

The Gulf of Guinea (Equatorial Atlantic Ocean) is characterised by spatial gradients of surface productivity due to coastal and offshore seasonal upwelling, and river plumes (Soltwedel, 1997). In front of the Niger River mouth, nutrient concentrations in the river plume are high due to direct fluvial influence, especially silicate, and due to river-induced upwelling, mainly nitrate and phosphate (Van Bennekom et al. 1978). Nevertheless, primary production is reduced because of the high input of suspended matter clouding the waters (Eisma et al. 1978). Conversely, along adjacent coasts, seasonal upwelling results in very high primary production and enhanced exported productivity to the seafloor (Soltwedel, 1997). Terrestrial organic matter supplied by the Niger River focuses at depths between 400 and 1500 meter depth along the so-called deep-water Niger delta (Altenbach et al., 2003). This deep-water delta constitutes a major physiographic unit of the Gulf of Guinea margin (Corredor et al., 2005) where high deltaic sedimentation rates and deformation by gravity driven tectonics result in a flattening of the continental slope down to water depths of more than 3000 m (e.g., Damuth, 1994; Riboulot et al., 2012). Sedimentary environments have 
been intensively studied along the slope because of abundant hydrocarbon resources (e.g., gas hydrate) (Bayon et al., 2007, 2011; Sultan et al., 2007, 2010, 2011, 2014; Rongemaille et al., 2011; Riboulot et al., 2012; Ruffine et al., 2013).

Four stations investigated in this paper are located at a depth of $\sim 1200 \mathrm{~m}$ along the deepwater Niger delta (Fig. 1, Table 1). These stations are bathed by oxygenated waters related to the mixing boundary between Antarctic Intermediate Water (AAIW) and North Atlantic Deep Water (NADW) (Bayon et al., 2011). All stations are close to each other (less than $1.2 \mathrm{~km}$ distance) (Fig. 1). Sites GMMC-01 and GMMC-02 are located within pockmark A at a distance of about $100 \mathrm{~m}$ from each other (Sultan et al., 2010). This 500-m-diameter pockmark consists in a circular ring-shape feature (Sultan et al., 2007, 2010, 2011, 2014), where ROV dives have revealed gas hydrate seepage from the sea-floor and patches of Bathymodiolus spp. attached to prominent carbonate concretions. Authigenic carbonates, defined as mudclast breccias rich in aragonite, were recorded in this pockmark (Bayon et al., 2007). The station GMMC-03 is located further south and slightly deeper along the margin in a topographic depression considered to be an inactive pockmark, designated "pockmark B". This feature formed following a collapse after a massive dissolution of gas hydrate (Sultan et al., 2007, 2010, 2011). Within pockmark B, sediments impregnated with natural oil have been observed in long cores (unpublished data, GUINECO-MeBo Cruise Report). The fourth site (GMMC04) is a reference station with no evidence of past or present seepage. It is located very close to pockmark A (within $100 \mathrm{~m}$ from the border of pockmark A).

\section{Material and Methods}

\subsection{Sediment coring}


During the GUINECO-MeBo Cruise aboard the RV "Pourquoi Pas?" (November 2011), sediment samples were collected with a Barnett-type multiple corer equipped with Plexiglas tubes (96 mm internal diameter) (Barnett et al., 1984). The multi-corer sampled the upper decimetres of the sediment column, the overlying bottom waters, and a comparatively undisturbed sediment-water interface (SWI). It was deployed once at each station. For this study, 2 cores were collected from each site.

The first core was sliced in three 1-cm-thick intervals from the SWI to 3-cm depth. Each sediment slice was immediately frozen $\left(-80^{\circ} \mathrm{C}\right)$ on board. Back at the laboratory, each slice was divided into 5 parts. Three of them were freeze-dried and assessed for sedimentary organic matter (TOC, C/N atomic ratio, amino acids) and mineralogy (see paragraphs 3.2 and 3.3). The two other subsamples were stored at $-80^{\circ} \mathrm{C}$ prior to analysis of phytopigments (see paragraph 3.3) and prokaryotic community composition (see paragraph 3.4) could be determined.

The second core was sliced horizontally every $0.5 \mathrm{~cm}$ from the sediment-water interface to $2-\mathrm{cm}$ depth, every $1-\mathrm{cm}$ between 2 and $5-\mathrm{cm}$ depth. This entire core was dedicated to the investigation of living (stained) foraminifera. Dead foraminifera were analysed in both $2-3 \mathrm{~cm}$ and 4-5 cm intervals (see paragraph 3.5 for details).

\subsection{Sedimentological analyses}

$\mathrm{X}$-ray powder diffraction $(\mathrm{XRD})$ is a technique for qualitative and semi-quantitative analysis of crystalline compounds (Table 2). The information obtained includes types and nature of crystalline phases present, structural make-up of phases, degree of crystallinity, amount of amorphous content, microstrain and size and orientation of crystallites. A typical diffraction spectrum consists of a plot of reflected intensities versus the detector angle 2-Theta 
or Theta depending on the goniometer configuration. The 2-Theta values for the peak depend on the wavelength of the anode material of the X-ray tube. Here, the bulk mineralogy was determined by XRD using a Siemens D500 X-ray diffractometer with $\mathrm{CuK} \alpha$ radiation $(1.5405$ $\AA$ wave length). Scans were done from $5^{\circ}$ to $80^{\circ} 2 \theta$ at $0.02^{\circ} / \mathrm{s}$, using $40 \mathrm{kV}$ accelerating voltage and $30 \mathrm{~mA}$ current. Peak identification and relative abundance estimates of minerals were determined using the EVA ${ }^{\circledR}$ interpretation software and the Diffract ${ }^{\circledR}$ software packages.

\subsection{Biogeochemical analyses}

All organic descriptors in the study were analysed in triplicate. Total Carbon (TC) and nitrogen $(\mathrm{TN})$ contents in sediments were measured on freeze-dried material by combustion using an automatic Thermo Finnigan EA 1112 Series Flash Elemental analyzer. Total Organic Carbon (TOC) content was similarly measured on freez-dried material after removal of carbonates with $2 \mathrm{M} \mathrm{HCl}$ from $50 \mathrm{mg}$ of powdered sample (Pastor et al., 2011). The reproducibility of these measurements was better than $5 \%$. $\mathrm{C} / \mathrm{N}$ ratios (i.e. TOC/TN) were expressed as atomic ratios. Total hydrolysable amino acids (THAA) and enzymatically hydrolysable amino acids (EHAA) were assessed in freeze-dried sediment subsamples. Bulk sediment was first crushed and passed through a $200-\mu \mathrm{m}$ mesh. THAA and EHAA were assayed according to Mayer et al. (1995). Approximately $15 \mathrm{mg}$ DW (Dry Weight) of sediment were mixed with $500 \mu \mathrm{L}$ of $6 \mathrm{M} \mathrm{HCl}\left(100^{\circ} \mathrm{C}\right)$ for $24 \mathrm{~h}$ under vacuum. Hydrolysed subsamples $(100 \mu \mathrm{L})$ were neutralised with $100 \mu \mathrm{L}$ of $6 \mathrm{M} \mathrm{NaOH}$, and buffered with $2 \mathrm{~mL}$ of $\mathrm{H}_{3} \mathrm{BO}_{3}(0.4 \mathrm{M}, \mathrm{pH}=10)$. Fluorescent derivatives were obtained by adding $200 \mu \mathrm{L}$ of an orthophtaldialdehyde (OPA) solution (100 mg OPA/1 mL methanol, $100 \mathrm{~mL}$ buffer $\mathrm{pH}=9.8$ and $0.05 \mathrm{~mL}$ mercaptoethanol) and $2 \mathrm{~mL}$ of phosphate buffer $(\mathrm{pH}=8)$ to $200 \mu \mathrm{L}$ of those 
samples. Total hydrolysable amino acids were quantified 2 min $30 \mathrm{~s}$ after OPA addition through fluorescence measurements (excitation wavelength $340 \mathrm{~nm}$ and emission wavelength 453 nm; Perkin Elmer LS55 fluorescence spectrometer). Enzymatically hydrolysable amino acids (EHAA) were extracted following a biomimetic approach (Mayer et al., 1995). Approximately $100 \mathrm{mg}$ of DW sediment were poisoned with a 1-mL solution containing sodium arsenate $(0.1 \mathrm{M})$ and pentachlorophenol $(0.1 \mathrm{mM})$ within a sodium phosphate buffer $(\mathrm{pH}=8)$, and were incubated for $1 \mathrm{~h}$ at room temperature to prevent the bacterial utilization of amino acids released after the addition of $100 \mu \mathrm{L}$ of proteinase $\mathrm{K}$ solution $(1 \mathrm{mg} / \mathrm{mL})$. Sediment was then incubated for $6 \mathrm{~h}$ at $37^{\circ} \mathrm{C}$. After centrifugation, $75 \mu \mathrm{L}$ of pure trichloroacetic acid were added to $750 \mu \mathrm{L}$ of supernatant to precipitate macromolecules, which are considered to be unsuitable for absorption. After another centrifugation, $750 \mu \mathrm{L}$ of the supernatant were hydrolyzed and processed as described for THAA. A blank accounting for possible degradation of the enzyme was carried out. Enzymatically hydrolysable amino acids were then quantified using the procedure described above for THAA. The EHAA/THAA ratios (expressed in \%) were computed for each station (Grémare et al., 2005; Pastor et al., 2011). This ratio is indicative of the lability of amino acids. For chlorophyll $a$ and pheophytin $a$, frozen $\left(-80^{\circ} \mathrm{C}\right)$ sediment subsamples (between 0.5 and $3.7 \mathrm{~g}$ ) were extracted (overnight, $4^{\circ} \mathrm{C}$ ) with $90 \%$ acetone (final concentration taking into account sediment water content). They were then centrifuged and their supernatant was used to assess chlorophyll a and pheophytin a according to Neveux and Lantoine (1993). The $[\mathrm{Chl} a /(\mathrm{Chl} a+$ Pheo $a)]$ ratios (expressed in \%) were computed for each station. This ratio is indicative of the freshness of phytopigment material.

\subsection{Prokaryotic community composition}


A $0.5 \mathrm{~g}$ sample of frozen sediment was extracted using the Power Soil DNA extraction kit (Mobio, USA) following the manufacturer's instructions. Bacteria and Archaea diversity was determined by 454 pyrosequencing using specific primers, 27F-519R for Bacteria and 349F806R for Archaea in MRDNA facilities (MR DNA, Shallowater, TX). PCR amplification was performed using HotStarTaq Plus Master Mix Kit (Qiagen, Valencia, CA) as follows: $94^{\circ} \mathrm{C}$ for 3 minutes, 28 cycles of $94^{\circ} \mathrm{C}$ for 30 seconds; $53^{\circ} \mathrm{C}$ for 40 seconds and $72^{\circ} \mathrm{C}$ for 1 minute. Finally an elongation step at $72^{\circ} \mathrm{C}$ for 5 minutes was performed. The different PCR products were mixed in equal concentrations and purified using Agencourt Ampure beads (Agencourt Bioscience Corporation, MA, USA). Sequencing was performed with a Roche 454 FLX titanium instrument following the manufacturer's guidelines. The sequencing data were processed using a proprietary analysis pipeline (www.mrdnalab.com, MR DNA, Shallowater, TX). After depletion of barcodes and primers in sequences, those showing a low quality score, i.e., sequences $<200 \mathrm{bp}$, with ambiguous base calls or with homopolymer runs exceeding $6 \mathrm{bp}$, were removed. Sequences are then denoised and chimeras removed. Operational taxonomic units were defined after removal of singleton sequences, clustering at $3 \%$ divergence $(97 \%$ similarity) (Dowd et al., 2008a, 2008b, 2011; Edgar, 2010; Capone et al., 2011; Eren et al., 2011; Swanson et al., 2011). OTUs were then taxonomically classified using BLASTn against a curated GreenGenes database (DeSantis et al., 2006). A cut-off similarity of 97\% was applied for species, 95\% for genera and $90 \%$ for families' assignation. In order to minimise the variability of libraries size and the pyrosequencing errors, sequences representing less than $0.1 \%$ were not considered.

\subsection{Foraminiferal faunal analysis}

Onboard, sediment samples $\left(2^{\text {nd }}\right.$ core) dedicated to foraminiferal analysis were stored in 
$250 \mathrm{~cm}^{3}$ bottles, which were filled with $95 \%$ ethanol. All samples were gently shaken for several minutes in order to obtain a homogeneous mixture. In the laboratory, $2 \mathrm{~g} / 1$ of Rose Bengal stain was added in the bottles and shaken once again. Rose Bengal staining is commonly used to identify benthic organisms that were alive at the time of the collection (Walton, 1952; Murray and Bowser, 2000). After 2 weeks, samples were sieved through 63 and $125 \mu \mathrm{m}$ mesh screens, and the sieve residues were stored in a mixture of $95 \%$ ethanol and Milli-Q water (50/50). Stained foraminifera belonging to the $>125 \mu \mathrm{m}$ size fraction were sorted in water, and stored in Plummer slides. It is known that Rose Bengal may stain the protoplasm of dead foraminifera, especially under the low-oxygen conditions (Corliss and Emerson, 1990; Bernhard, 2000). As a consequence, a strict application of the staining criteria was applied in this study. Foraminifera were considered "live" if all chambers except the last one were stained bright pink. Doubtful individuals were compared against perfectly stained individuals of the same species. Non-transparent agglutinated tests were broken on many occasions in order to inspect the interior. Most living foraminifera were identified to species level (see Appendices A and B for census data). Because samples were preserved and sorted in ethanol, many soft-shelled monothalamous foraminifera may have shrunk and may have become unrecognisable during picking. Thus, our counts will likely underestimate the softwalled foraminiferal group. Using a scanning electron microscope at Ifremer (FEI QUANTA 200 equipped with an Oxford Instrument Energy Dispersive Spectroscopy), we obtained digital photographs of picked foraminiferal individuals belonging to dominant species (Fig. 2). At each station, we calculated different diversity indices. First of all, we calculated the simple diversity S representing the number of taxa. The simple diversity $\mathrm{S}$ does not take into account the abundance of species and is highly sensitive to sample size so we also determined a rarefaction curve for each station and determined the related $E\left(S_{100}\right)$ value. The $E\left(S_{100}\right)$ value represents the number of species that would be identified after picking 100 specimens. 
We also calculated the Shannon index H' (log base e), completed by the Evenness index E (Hayek and Buzas, 1997) as described in Murray (2006). We calculated the Berger-Parker Index, which corresponds to the percentage value of the most abundant species at each station (Table 3). Following the picking of living (stained) foraminifera, sediment samples were dried in an oven at $50^{\circ} \mathrm{C}$. Dead foraminifera belonging to the $>125 \mu \mathrm{m}$ fraction were analysed in both 2-3 cm and 4-5 cm intervals. We divided samples in aliquots using an Otto micro-splitter in order to get at least 200 individuals per sediment interval (Table 4). Once again, we used scanning electron microscopy (SEM) to examine the dead specimens in order to evaluate the effect of diagenesis on foraminiferal tests (e.g., dissolution, authigenic carbonate either inside or outside chambers) (Fig. 2).

\subsection{Isotopic measurements on foraminiferal tests}

The carbon and oxygen isotope data were generated on hand-picked foraminifera from the $>125 \mu \mathrm{m}$ fraction and analysed with an automated carbonate reaction device (Kiel III) coupled to a Thermo-Finnigan MAT253. Calibration to the international carbonate standard NBS-19 and in-house standard NAXOS revealed a standard deviation of $0.04 \%$ and $0.03 \%$ o

for replicate $\delta^{13} \mathrm{C}$ and $\delta^{18} \mathrm{O}$ measurements. Four abundant species, Bolivina albatrossi, Ceratobulimina contraria, Melonis barleeanus and Uvigerina peregrina, were measured (Table 5). Both Rose-Bengal stained (living) and dead specimens were included in the analyses. Dead foraminifera were selected based on criteria of test preservation (i.e., color, transparency and brightness determined by stereomicroscopy). In addition, some authigenic carbonate mudclasts and dead (and altered) foraminifera affected by authigenic carbonate (species $C$. contraria only - observed by SEM) were selected from station GMMC-02 (Fig. 2). Most of the measurements were performed on individual specimens (generally when their 
weight exceeded $20 \mu \mathrm{g}$ ). In some cases smaller individuals were grouped to generate enough mass for analyses. Due to its very small size, B. albatrossi was always grouped for analyses. If specimens were grouped, this was always done with specimens of similar size. Furthermore, the sample weight was always recorded to allow the comparison of isotope data with foraminiferal size or weight. All foraminifera were cleaned prior to the analyses. Specimens were rinsed twice in individual Eppendorf tubes with ultrapure water $(100 \mu l)$, followed by two rinses in methanol $(100 \mu \mathrm{l})$ and finally with two rinses in ultra pure water $(100 \mu \mathrm{l})$. During the methanol rinses, the Eppendorf tubes were placed in an ultrasonic bath for 5 seconds.

For comparison, the $\delta^{18} \mathrm{O}$ of calcite in equilibrium with bottom water for a given temperature $\mathrm{T}\left({ }^{\circ} \mathrm{K}\right)\left(=\delta^{18} \mathrm{O}_{\text {e.c. }}\right)$ was calculated with the following equation (McCorkle et al., 1997):

$$
\delta^{18} O_{\text {e.c. }}(S M O W)=\left(\exp ^{\left(\left(2.78 \times 10^{3} / T^{2}\right)-\left(2.89 / 10^{3}\right)\right.} \times\left(\delta^{18} O w+1000\right)\right)-1000
$$

where $\delta^{18} \mathrm{Ow}$ is the oxygen isotopic composition of bottom water relative to SMOW $(+0.1 \%$ in Rongemaille et al., 2011). This equation is derived from the expression for the calcite-water fractionation factor determined by O’Neil et al. (1969), incorporating a revised estimate of the $\mathrm{CO}_{2}$-water fractionation factor (1.0412 rather than 1.0407) as discussed by Friedman and O’Neil (1977). The SMOW-PDB conversion is calculated according the equation (Friedman and O’Neil, 1977):

$$
\delta^{18} O_{\text {e.c. }}(P D B)=\left(0.97006 \times \delta^{18} O_{\text {e.c. }}(S M O W)\right)-29.94
$$


The $\delta^{18} \mathrm{O}$ of biogenic aragonite for a given temperature $\mathrm{T}^{\prime}\left({ }^{\circ} \mathrm{C}\right)\left(=\delta^{18} \mathrm{O}_{\text {aragonite }}\right)$ can be calculated with the following equation (Grossman and $\mathrm{Ku}, 1986$ ):

$\delta^{18} O_{\text {aragonite }}(P D B)=\delta^{18} O w+\left(20.6-T^{\prime}\right) / 4.34$

It gives a value of $+2.8 \%$ for the $\delta^{18} \mathrm{O}_{\text {e.c. }}$ related to bottom water and a value of $+3.7 \%$ for $\delta^{18} \mathrm{O}_{\text {aragonite }}$

\section{Results}

4.1 Mineralogy

X-ray powder diffraction revealed a contribution of terrigeneous minerals such as quartz, kaolinite and muscovite at all stations (Table 2). Calcite was also detected, likely related to benthic and planktonic foraminiferal shells and bioclasts that are abundant at all sites. Stations GMMC-01 and GMMC-02, which are located in pockmark A, are characterised by aragonite and high-magnesium calcite (Table 2). Noticeably, aragonite consists of acicular crystals (> $10 \mu \mathrm{m})$ and botryoidal-like concretions, which cement both terrigeneous clay-rich and biogenic material (Fig. 3). They form macroscopic porous mudclasts in which dead foraminifera are occasionally embedded (Fig. 4).

\subsection{Particulate organic matter}

TOC content in surface sediments $(0-3 \mathrm{~cm})$ ranges between $1.2 \pm 0.2 \% \mathrm{DW}$ at station GMMC-01 (pockmark A) and 1.9 $\pm 0.1 \%$ DW at station GMMC-03 (Fig. 5). The C/N ratio shows only small changes between stations with values ranging between $11.1 \pm 0.4$ at station GMMC-03 and $11.8 \pm 0.9$ at station GMMC-01. The amounts of total hydrolysable amino 
acids (THAA) range between $3.56 \pm 0.15 \mathrm{mg} / \mathrm{g}$ DW at station GMMC-02 and $5.54 \pm 0.34$ $\mathrm{mg} / \mathrm{g} \mathrm{DW}$ at GMMC-03. EHAA values vary between 0.56 and $0.78 \mathrm{mg} / \mathrm{g} \mathrm{DW}$, with the minimum recorded at station GMMC-02 and the maximum at station GMMC-03. EHAA/THAA ratio is quite low at all sites with values ranging between 14.1 and $17.6 \%$. Chl $a$ content is minimal at the reference station GMMC-04 $(0.92 \pm 0.26 \mu \mathrm{g} / \mathrm{g})$ and maximal at station GMMC-01 $(3.60 \pm 2.54 \mu \mathrm{g} / \mathrm{g})$. [Chl $a /(\mathrm{Chl} a+$ Pheo $a)]$ ratio ranges between 45 and 50\% at stations GMMC-01, GMMC-02 and GMMC-03 but falls to 14\% at station GMMC-04 (Fig. 5).

\subsection{Prokaryotic community composition}

Stations GMMC-01 and GMMC-02 (pockmark A) exhibit a different bacterial community composition compared to stations GMMC-03 (pockmark B) and GMMC-04 (reference). All stations yielded between 60 and 76 different families. Most of the sequences affiliate to Proteobacteria, with sequences associated with Gammaproteobacteria being the more abundant (around 50\%) followed by Deltaproteobacteria sequences. The relative abundance of the sulphate-reducing bacteria (SRB) affiliated to the Deltaproteobacteria, increases with sediment depth (Fig. 6A-B). Additionally, sequences related to genera Acidithiobacillus, Cycloclasticus, Defluciicoccus, Granulosicoccus, Leptospirullum, Leucothrix, Nitrosococcus, Nitrospina, Rhodobacter and Thiobacillus are observed in all samples with a relative abundance above $1 \%$.

Among genera involved in the sulphur cycle, the sulphur-oxidising bacteria (SOB) are dominant at stations GMMC-01 and GMMC-02 (pockmark A) with relative abundance above 20\% (Fig. 6B). Acidithiobacillus related sequences are dominant at those stations, representing up to $18 \%$ in some sediment intervals, but less than $8 \%$ in samples from stations 
GMMC-03 and GMMC-04. Other abundant SOB at stations GMMC-01 and GMMC-02 are Thiobacillus, Thiothrix and Leucothrix. The sulphate-reducing community is represented by bacteria affiliated to Desulfobulbaceae, and in the deeper samples to Desulfobacteraceae and Syntrophobacteraceae (Fig. 6B). The methanotroph community is composed of two families, Crenotrichaceae and Methylococcaceae, with two dominating methanotroph members, Crenothrix and Methylomonas, representing up to 8\% at station GMMC-01 but less than 1\% at stations GMMC-03 and GMMC-04. The relative abundance of these three metabolic groups (ie., sulphur-oxidising, sulphate-reducing and methanotroph) reaches up to $42 \%$ at pockmark A but less than $15 \%$ at both pockmark B and the reference site (Fig. 6B). In these latter stations, beside Acidothiobacillus, the dominant bacteria are affiliated to the nitrifying Nitrosococcus and to unaffiliated genera within the families Sinobacteriaceae and nonsulphur Rhodospirillaceae. At all stations, the diversity of Archaea is highly dominated (76 to $88 \%$ ) by a Nitrosopumilus-related archaeon.

\subsection{Live (stained) Foraminiferal Faunas}

Foraminiferal standing stocks range between 169 Ind./100 $\mathrm{cm}^{2}$ at station GMMC-04 and 365 Ind./100 $\mathrm{cm}^{2}$ at station GMMC-03 (Table 3). Simple diversity (S) varies between 40 (GMMC-04) and 59 (GMMC-01). Shannon Index H' is minimal at station GMMC-04 (3.23) and maximal at station GMMC-01 (3.54). Both Evenness and Berger-Parker indices show only minor variability between stations.

Perforate calcareous species dominate foraminiferal faunas at all stations $(>65 \%)$. Their contribution is highest at station GMMC-03, where they account for $83 \%$ of the living community. The agglutinated species represent between 14 and $33 \%$ of foraminiferal assemblages (Appendix A). Of the perforate species, Bolivina albatrossi (calcite), 
Ceratobulimina contraria (aragonite) and Melonis barleeanus (calcite) are dominant at all sites (Fig. 7). Ceratobulimina contraria is the most abundant species $(>20 \%)$ at stations GMMC-01, GMMC-02 and GMMC-04. At station GMMC-03, it constitutes 8\% of the living fauna. Melonis barleeanus ranges between 6\% at station GMMC-02 and 25\% at station GMMC-01. The relative abundance of Bolivina albatrossi varies from $6 \%$ at station GMMC01 to $13 \%$ at station GMMC-03. In addition, Uvigerina peregrina is present at all sites with contributions lower than 7\%. Uvigerina hispida and Globobulimina spp. are relatively abundant (9\% and 7\% respectively) at station GMMC-03 (Fig. 7). They are also present at station GMMC-02. Pullenia bulloides ( 7\%) and Cibicidoides robertsonianus $(6 \%)$ and the agglutinated species Hormosina globulifera $(6 \%)$ are relatively more abundant at the reference station GMMC-04 compared to the 3 other sites. Agglutinated species in the genus Lagenammina account for $\sim 5 \%$ of living communities at all sites. In general, the foraminiferal assemblages are very similar between all stations. The only significant difference in terms of faunal composition (based on absolute abundances, $\mathrm{p}<0.05$, Kruskall-wallis test) is between station GMMC-04 and station GMMC-01.

\subsection{Dead Foraminiferal faunas}

The Shannon index (H') varies between 2.66 at station GMMC-03 (pockmark B) and 3.28 at the reference station GMMC-04 (Table 4); stations GMMC-01 and GMMC-02 from active pockmark A show intermediate values. The Evenness index E is lowest at GMMC-03 $(0.39-0.45)$ and the Berger-Parker value is the highest at this site $(0.29-0.26)$ reflecting the dominance of Bolivina albatrossi. At other stations, the Berger-Parker index ranges between 0.10 and $015 . \mathrm{E}\left(\mathrm{S}_{100}\right)$ is the highest at the reference station (34-32) (Table 4). 
Bolivina albatrossi is the dominant species among dead faunas at station GMMC-03 $(\sim 27 \%)$ and at station GMMC-04 ( 14\%) (Fig. 8). It constitutes $10 \%$ of assemblages at stations GMMC-01 and GMMC-02, from the active pockmark A. Bulimina marginata $(\sim 10 \%)$ Osangularia culter $(\sim 8 \%)$, and Cibicidoides kullenbergi $(\sim 8 \%)$ are also typical at both these stations. Bulimina buchiana is quite abundant at station GMMC-03 ( 7\%) compared to other sites. Uvigerina peregrina contributes $\sim 10 \%$ of the fauna at all stations (Fig. 8). In all studied depth intervals, calcareous species represent more than $90 \%$ of dead assemblages (Appendix B). The 2 first axes of the Principal Component Analysis (Q-mode) (PCA1 and PCA2) explain more than $86 \%$ of the overall variability of samples (Fig. 9). The PCA1 axis is loaded by Bolivina albatrossi $(+0.72)$ and Bulimina buchiana $(+0.24)$ on the positive side, and Bulimina marginata (-0.45), Cibicidoides kullenbergi (-0.29) and Osangularia culter $(-0.23)$ on the negative side. The PCA2 axis is defined by Bulimina inflata $(+0.55)$, Bulimina marginata $(+0.43)$ and Bolivina albatrossi $(+0.30)$ on its positive side, and by Melonis barleeanus (-0.31) and Globobulimina spp. (-0.25) on its negative section. Both intervals from each station plot in a fairly well-delimited area of the PCA plot (Fig. 9). The 4 intervals from both stations GMMC-01 and GMMC-02 are grouped together.

\subsection{Stable isotopes in living and dead foraminiferal faunas}

In total, 154 isotope measurements were performed. Of these, 12 analyses were carried out with Bolivina albatrossi, 44 with Ceratobulimina contraria, 52 with Melonis barleeanus, 38 with Uvigerina peregrina, 4 with $C$. contraria covered with authigenic carbonate, and 4 with authigenic carbonate mudclasts. The isotope data for living (stained) and dead foraminifera showed that each species has its own range of isotope signatures (Fig. 10). Generally heavier $\delta^{13} \mathrm{C}$ values $(>0.5 \%$ ) were recorded in aragonitic $C$. contraria and lighter, 
or more negative $\delta^{13} \mathrm{C}$ values were observed in the calcitic taxa. The most negative $\delta^{13} \mathrm{C}$ values were recorded in the intermediate infaunal M. barleeanus from seep station GMMC-02 $(-1.95 \pm 0.25 \%$, the average including living and dead specimens). Less variation was observed in the $\delta^{18} \mathrm{O}$ values among the taxa, the average $\delta^{18} \mathrm{O}$ of all measurements being 3.29 $\pm 0.63 \%$. Furthermore, no clear correlations were observed between specimen size (or weight) and isotopic composition, including both $\delta^{13} \mathrm{C}$ and $\delta^{18} \mathrm{O}$ composition.

Sites GMMC-01 and GMMC-02 from the pockmark A both showed generally more negative $\delta^{13} \mathrm{C}$ values than the pockmark B (GMMC-03) and the reference (GMMC-04) station (Fig. 10). This pattern was especially clear for C. contraria, M. barleeanus and U. peregrina where significantly lower $\delta^{13} \mathrm{C}$ values were recorded from the seep sites than from reference or depression sites (Kruskall Wallis test, $\mathrm{p}<0.05$, dataset included both living and fossil fauna). If only the living specimens were considered, $\delta^{13} \mathrm{C}$ values of $C$. contraria, $M$. barleeanus and $U$. peregrina were also significantly lower at the seep sites than at the reference and non-active site (Kruskall Wallis test, $\mathrm{p}<0.05$ ). Only the $\delta^{13} \mathrm{C}$ values of $B$. albatrossi did not follow this pattern. Nevertheless, the $\delta^{13} \mathrm{C}$ values from the seep foraminifera $(-1.20 \pm 1.73 \%$, average of all taxa) were still much heavier than values recorded in altered $C$. contraria (affected by authigenic carbonate) $(-17.21 \pm 3.55 \%$ ) and authigenic carbonate mudclasts $\left(-26.22 \pm 0.65 \%\right.$ ) (Fig. 11). The foraminiferal $\delta^{18} \mathrm{O}$ composition did not statistically vary between different stations.

In general, the $\delta^{13} \mathrm{C}$ signatures of dead foraminifera from the seep sites were somewhat lighter than the living foraminiferal $\delta^{13} \mathrm{C}$ signatures recorded from the same stations. For example, significantly lighter $\delta^{13} \mathrm{C}$ values were recorded for fossil M. barleeanus (GMMC-01 $-1.87 \pm 0.33 \%$, GMMC-02 $-2.24 \pm 0.22 \%$ ) than for living M. barleeanus (GMMC-01 $-1.59 \pm$ $0.14 \%$, GMMC-02 $-1.87 \pm 0.23 \%$ ) from the seep sites (Mann Whitney test, $\mathrm{p}<0.05$ ). In 
addition, fossil tests of $B$. albatrossi and $C$. contraria appeared visually lighter than living specimens from station GMMC-02, although these relationships were not statistically significant. In contrast, $\delta^{13} \mathrm{C}$ signature of living and fossil $U$. peregrina was relatively similar at each site, including the seep stations.

The foraminiferal $\delta^{18} \mathrm{O}$ composition within one station was relatively homogenous and did not vary much among living and dead specimens (Fig. 10). A clear difference was only observed for $U$. peregrina from stations GMMC-01 and GMMC-02 where the average $\delta^{18} \mathrm{O}$ composition of dead foraminifera was $0.57 \%$ and $0.82 \%$ higher than for living foraminifera, respectively. In addition, at station GMMC-02, the $\delta^{18} \mathrm{O}$ composition of dead C. contraria was $0.83 \%$ heavier than that recorded for living specimens.

\section{Discussion}

\subsection{Sedimentary and biogeochemical features}

Pockmark A (stations GMMC-01, 02) is characterised by hemipelagic sediments, including foraminiferal bioclasts (Fig. 5, Table 2). The organic compounds originate from marine sources (low bioavailability of amino acids, $\mathrm{C} / \mathrm{N}$ ratio $\sim 12$ ) and are associated with minerals inherited from adjacent continental areas (e.g., kaolinite, quartz, micas). Here, the surficial sediments are dominated by prokaryotic groups (e.g., Acidithiobacillaceae, Thiotrichaceae, Crenotrichaceae, Desulfobulbaceae) relying on aerobic methanotrophy, sulphate reduction and sulphur oxidation. Their occurrence is likely to be related to upward diffusion of methane and hydrogen sulphide produced in deep sediment layers. However, the absence of anaerobic methanotrophic Archaea (ANME) suggests that gas seepage was relatively moderate during the sampling period (November 2011) (Haas et al., 2010). The 
presence of authigenic aragonite in surface samples suggests that ANME-mediated oxidation of high methane flux has occurred close to the sediment-water interface in the recent past, probably during enhanced seep events (e.g., Burton, 1993; Aloisi et al., 2000, Luff and Wallman, 2003; Bayon et al., 2007; Haas et al., 2010; Nöthen and Kasten, 2011; Berndt et al., 2014; Sultan et al., 2014) (Figs. 3 and 4). Furthermore, the presence of both authigenic high $\mathrm{Mg}$-calcite and aragonite in surface sediments points to an alternation of weak seepage with stronger seepage events (Nöthen and Kasten, 2011). In addition, the extremely depleted $\delta^{13} \mathrm{C}$ signatures of carbonate mudclasts and dead foraminifera covered by aragonite $(-26.2 \%$ and $17.2 \%$ respectively) confirm the role of anaerobic methane oxidation (AOM) in the formation of authigenic carbonates close to the sea floor in the recent past (Nöthen and Kasten, 2011) (Fig. 11). Our isotope results are consistent with previous measurements performed on bulk sediments rich in authigenic aragonite-rich carbonate gathered from interface and Kullenberg cores in pockmark $\mathrm{A}\left(\delta^{13} \mathrm{C}\right.$ between -23.3 and $-23.9 \%$, $\delta^{18} \mathrm{O}$ between 3.8 and $4.3 \%$ o $)$ (Rongemaille et al., 2011).

At station GMMC-03, located in pockmark B, sediments have a higher organic matter content compared to other sites $(1.9 \pm 0.1 \% \mathrm{DW})$. However, the bioavailability and potential source areas appear similar even if a slight decrease is noted in the nutritional value of organic matter (i.e., EHAA/THAA) between stations GMMC-01, GMMC-02 and GMMC-03 (Fig. 5). This suggests that pockmark B behaves like a preferential burial area for degraded marine organic matter. Methanotrophic bacteria are absent in this setting and both sulphur-oxidising and sulphate-reducing functional groups are much less abundant compared to the active pockmark A (Fig. 6B). As suggested in Sultan et al. (2010), pockmark B represents a senile stage of a previously active pockmark (compared to the apparently younger form pockmark A), where the seafloor has collapsed during massive dissociation of gas hydrates. Following 
the event, the related depression has been gradually filled by hemipelagic and organicallyenriched sediments.

Station GMMC-04 appears similar to GMMC-03 in terms of recent sedimentary facies. The only major difference is the relatively low organic-matter content and the relatively low quality of phytodetritus (Fig. 5). In this study, station GMMC-04 is thus considered to represent non-seep conditions.

\subsection{Living (stained) Foraminifera: An ecological snapshot of a quiet seepage episode.}

The ecological interpretation of foraminiferal data is quite complex in pockmarks where small-scale (decimetric to metric) biozonation is directly related to both the spatial heterogeneity and temporal variability of biogeochemical processes (e.g. Sen Gupta and Aharon, 1994; Rathburn et al., 2003; Heinz et al., 2005). To encompass the spatial variability of faunas, it is recommended to analyse three replicates from each sampling site (Schönfeld et al., 2012). In this study, only two cores were available, one dedicated to environmental parameters, and the other to foraminiferal faunas. Therefore, readers should keep in mind that our interpretations of living faunas may be slightly biased by spatial variability.

In accordance with previous studies dealing with living (stained) foraminifera from cold seep areas (e.g., Sen Gupta and Aharon, 1994; Kitazato, 1996; Sen Gupta et al., 1997; Rathburn et al., 2000; 2003; Lobegeier and Sen Gupta, 2008; Martin et al., 2010), no major faunal differences were noted between seep and non-seep environmental settings. The only statistically significant difference was found between the reference site (GMMC-04) and one of the two pockmark-A stations (GMMC-01) (based on absolute abundances, $\mathrm{p}<0.05$, Kruskall-Wallis test). However, this difference is not related to an obvious change in "key species" as all the stations are characterised by a relatively even distribution of major species 
(Ceratobulimina contraria, Melonis barleeanus, Bolivina albatrossi) $(\mathrm{E}>0.52)$ and highdiversity faunas (Simple diversity $>40, \mathrm{H}^{\prime}>3.23$ ).

To our knowledge, Ceratobulimina contraria (Reuss), which is the most abundant aragonitic species in our study area, has not previously been documented in seep areas. However, it has been described from the continental margin of Gulf of Guinea either as Ceratobulimina pacifica Cushman and Harris (Altenbach et al. 2003) or as Robertinoides chapmani (Heron-Allen and Earland) (Licari et al., 2003; Licari and Mackensen, 2005). It has been shown to live between $\sim 1250 \mathrm{~m}$ and $\sim 2200 \mathrm{~m}$ depth in the Gulf of Guinea and the northern Angola Basin (Licari et al., 2003; Licari and Mackensen, 2005). In all cases, it seems that this species thrives in well-ventilated benthic environments $(>180 \mu \mathrm{mol} / \mathrm{L})$ characterised by a moderate to high sedimentary organic content $(1.2-3.0 \%$ DW) and relatively deep oxygen penetration depth (between 2 and $8 \mathrm{~cm}$ within sediments) (Licari et al., 2003; Licari and Mackensen, 2005). It is also worth noting that Altenbach et al. (2003), who studied living and dead foraminifera from more than 120 stations from the Gulf of Guinea (11 transects between 30 and $5000 \mathrm{~m}$ depth), did not identify C. contraria as an abundant taxon, presumably due to its limited geographical and bathymetrical distribution.

Melonis barleeanus (Williamson) is a major calcitic species living in the study area. It occupies a deep infaunal microhabitat at all stations (Appendix A). Panieri (2005) reported $M$. barleeanus from a hydrocarbon seep in the Rockall Trough and suggested that this species populates cold seeps because bacteria are particularly abundant there. On the other hand, Altenbach et al. (2003) failed to find M. barleeanus in the Gulf of Guinea, possibly because their study focussed only on shallow infaunal and epifaunal taxa. In other (non-seep) studies this taxon is commonly described from relatively organic-matter enriched sediments from upper slope and canyon settings (e.g., Fontanier et al., 2002; 2003; 2005; 2008a; Licari et al., 2003; Licari and Mackensen, 2005; Eberwein and Mackensen, 2006; Koho et al., 2007; 2008; 
Duros et al., 2011; 2013). Licari et al. (2003) and Licari and Mackensen (2005) described this infaunal species at $\sim 1300 \mathrm{~m}$ depth in the Gulf of Guinea and the northern Angola Basin. Its preference for degraded organic matter (and related bacterial pool) and its ability to thrive in dysoxic conditions within sediments may explain its occurrence and infaunal distribution in our study area (Caralp, 1989, Licari et al., 2003; Panieri, 2005; Fontanier et al., 2003; 2005).

Bolivina albatrossi Cushman has previously been reported along the upper- and mid slope of the Gulf of Guinea in sediments with high organic content and reduced oxygen concentrations (Schiebel, 1992; Timm, 1992; Altenbach et al., 2003). Moreover, Sen Gupta and Aharon (1994) have found B. albatrossi associated with bacterial mats and hydrate mounds in cold seeps from the Gulf of Mexico, an area characterised by an intermittent venting rate. This species has also been recorded in $\mathrm{H}_{2} \mathrm{~S}$-rich anoxic sediments, some millimetres under Beggiatoa mats sustained by slow seepage (Sen Gupta et al., 1997). Therefore, B. albatrossi is considered a "small, infaunal, $\mathrm{H}_{2} \mathrm{~S}$ tolerant, opportunistic species" (Sen Gupta et al., 1997), which may bloom at times (e.g. seep events) that are hostile for other species. At the time of this study, the relatively moderate contribution of B. albatrossi to total standing stocks suggests that the gas seepage and environmental stress conditions were relatively low. This is also consistent with our geochemical analyses and the absence of methanotrophic Archaea in surface sediments.

Uvigerina hispida and Globobulimina spp. are present at station GMMC-03 (pockmark B) where organic content is higher. Uvigerina hispida Schwager was described as Uvigerina auberiana d'Orbigny in Licari et al. (2003) and Licari and Mackensen (2005). Both of these taxa are commonly found in organic-rich/low-oxygen environments (e.g. Sen Gupta and Machain-Castillo, 1993; Schmiedl et al., 1997; Licari et al., 2003; Licari and Mackensen 2005). Their relative abundance $(\sim 15 \%)$ at pockmark B may be related to a preferential burial of altered organic matter at this site. Uvigerina peregrina is a subsidiary species in our study 
area, accounting for less than $7.5 \%$ of the assemblage (maximum value recorded in the reference site). In active cold seeps in the Pacific Ocean, this species made a major contribution to the living faunas (Rathburn et al., 2000; 2003; Bernhard et al., 2002; Heinz et al., 2005).

\subsection{Dead Foraminifera: An integrative and reliable proxy for episodic seepages}

The comparison between living foraminiferal faunas (i.e., biocoenoses) and dead assemblages (i.e., thanatocoenoses) in modern sediments is essential in order to obtain a reliable calibration of proxies based on microfossils. It can provide insights into taphonomic changes during burial processes and the reliability of the paleoecological signal preserved in ancient sediments (de Stigter et al., 1999). Recent papers dealing with deep-sea foraminifera have assessed the importance of taphonomic mechanisms in canyon settings (e.g., Fontanier et al., 2008b; 2012; Duros et al., 2012; 2014). They underline the fact that population dynamics can explain differences observed between living and dead faunas. Living assemblages represent a snapshot of the fauna at a particular time point, whereas dead faunas are a complex integration of foraminifera accumulating at the sampling site for many years, decades, and sometimes, centuries. Opportunistic species that were absent when a living community was sampled, because conditions at that time were unfavourable, may be a significant contributor to thanatocoenoses, particularly if the sampling site is subject to environmental instability (e.g., enhanced seepages) over time. That being said, the difference between living and dead faunas may be related to other mechanisms such as differential dissolution and/or fragmentation of fragile foraminiferal tests and the transport of allochtonous material at the sampling site (e.g., De Stigter et al., 1999; Fontanier et al., 2008b; 2012; Duros et al., 2011; Duros et al., 2014). 
Bulimina marginata, which is rare $(<2.5 \%)$ in living communities from our study area, is a dominant taxon in the dead assemblages $(>10 \%)$ at both pockmark A stations. This species has been recorded in many atypical sedimentary environments characterised by instability. For instance, it was recorded as a pioneer species able to colonize freshly deposited turbidite sediments in the Cape Breton Canyon (NE Atlantic) (Hess et al., 2005; Hess and Jorissen, 2009). It was also documented as a dominant taxon in low-diversity opportunistic faunas living in bauxite-derived industrial red mud dumped into the deep-sea Cassidaigne Canyon (Western Mediterranean Sea) (Fontanier et al., 2012). Furthermore, it was described in organic-rich sediments from outer-shelf environments, where it behaved like an opportunistic, phytophagous taxon (e.g., Duchemin et al., 2007). Moreover, it is one of the most opportunistic species capable of colonizing drill-cuttings muds enriched in organic compounds deposited in large quantities around oilrigs located in deep-sea settings (unpublished data, Fontanier C.). That said, B. marginata has never been documented as an abundant species (either living or dead) at cold seeps. So the important contribution of $B$. marginata in the dead faunas from pockmark A, and its scarcity at other sites (GMMC-03 and -04), are really intriguing. Differential dissolution of tiny and/or sensitive foraminiferal taxa (e.g., Bolivina, Globobulimina, Ceratobulimina, Gavelinopsis) may explain such faunal differences between stations where spatial and temporal variability of alkalinity within the sediment is likely to be a key factor controlling fossilisation. Assuming that the composition of dead foraminiferal assemblages is mainly constrained by population dynamics, we propose that B. marginata responds opportunistically to recurrent and sudden seep events occurring in pockmark A. Advective flows of methane through the sea-floor, sulphide enrichment in the uppermost sediment, and the proliferation of prokaryotes involved in anaerobic methane oxidation and sulphur cycles, could trigger its opportunistic proliferation in living communities and its relatively high contribution in the dead assemblages. Remarkably, 
Bolivina albatrossi is dominant $(>25 \%)$ in the dead faunas from pockmark B (station GMMC-03), which represents a collapsed, senile stage of a previously active pockmark. Due to the opportunistic nature of $B$. albatrossi, the abundance of this small, infaunal, $\mathrm{H}_{2} \mathrm{~S}$ tolerant, opportunistic species (Sen Gupta and Aharon, 1994; Sen Gupta et al., 1997) in the dead faunas may be the consequence of the ephemeral bacterial mats sustained by episodic but limited seepages prevailing in pockmark B (Sen Gupta et al., 1997).

\subsection{Stable Isotopes: A way to detect discrete hydrate-gas fluids}

The $\delta^{13} \mathrm{C}$ values in living and dead foraminifera at both pockmark-A stations show some influence of methane-enriched fluid. Compared to both reference and pockmark-B stations, a shift of $1 \%$ to lower $\delta^{13} \mathrm{C}$ values is observed for Ceratobulimina contraria, Uvigerina peregrina and Melonis barleeanus. Similar moderate depletion in living and dead foraminifera was documented in other cold-seep areas (Sen Gupta and Aharon, 1994; Sen Gupta et al., 1997; Rathburn et al., 2000; Rathburn et al., 2003; Mackensen et al., 2006). This intraspecific $-1 \%$ depletion cannot be related to a putative enhanced mineralization of organic matter in pockmark A as organic compounds focus preferentially at pockmark B station and bioavailability of amino acids is quite similar between all stations (Fontanier et al., 2006). Alternatively, ${ }^{13} \mathrm{C}$-depleted food sources (e.g., methane-oxidizing bacteria) and/or prokaryotic

symbionts have been suggested to contribute to the depletion of $\delta^{13} \mathrm{C}$ signatures of foraminiferal shells (Sen Gupta and Aharon, 1994; Rathburn et al., 2003; Hill et al., 2004; Panieri, 2006; Mackensen et al., 2006). However, we believe that the slight depletion in $\delta^{13} \mathrm{C}$ signatures may be related to currently low rates of methane discharge or to intermittent episodes of seawater flow into the sediments (Torres et al., 2003). 
In contrast, a strong negative $\delta^{13} \mathrm{C}$ anomaly was recorded in altered Ceratobulimina contraria and carbonate mud clasts. This pattern can be attributed to diagenetic processes, such as post-mortem authigenic carbonate overgrowth in high-alkalinity pore water when the SMTZ was close to sediment-water interface (Torres et al., 2003; Martin et al., 2004; Barbieri and Panieri, 2004; Wiedicke and Weiss, 2006) (Fig. 2). Our $\delta^{13} \mathrm{C}$ data for dead, poorly preserved foraminifera imply that outmost care should be taken when building a chronology of seep activity for centuries and millennia in long archives (Martin et al., 2004), as diagenetic processes are likely to leave their imprint on foraminifera. However, a SEM-based selection of well-preserved fossil specimens (i.e., with no signs of overgrowths on the test surfaces or of changes in texture) provides a reliable approach for investigating and interpretating of contemporaneous pockmark activity and related flows of methane-rich fluid.

\section{Conclusions}

The main objective of this study was to explore whether fossilising benthic foraminifera are reliable and relevant proxies to detect gas hydrate emission in a pockmark field from the deep-water Niger delta (Gulf of Guinea, Equatorial Atlantic Ocean). Our observations lead to the following conclusions.

1. Living foraminiferal faunas at all sites are characterised by relatively high diversity and evenness, with species adapted to thrive in sediments enriched in degraded organic matter. At the time of sampling (November 2011), methane seepage in pockmark A apparently was not sufficiently strong to influence the composition of the living fauna. 
2. The $\delta^{13} \mathrm{C}$ signal of living and dead (but well-preserved) foraminiferal species (Ceratobulimina contraria, Melonis barleeanus, Uvigerina peregrina) was moderately depleted in pockmark A compared to reference and pockmark B stations. This depletion is likely related to (1) present-day imprints of aerobic methane oxidation in upper sediments and (2) a potential effect of the prokaryotic ${ }^{13} \mathrm{C}$-depleted biomass as a potential food source for benthic foraminifera. Overgrowth of authigenic carbonate on altered foraminifera, when the sulphate-methane transition zone was close to the sediment-water interface, generates an important shift to lower $\delta^{13} \mathrm{C}$ values.

3. Dead faunas from upper sediment layers carry a time-averaged signal, which integrates (1) population dynamics constrained by the temporal variability of methane emission and (2) taphonomic biases during ongoing fossilisation. They reveal major faunal differences between stations, suggesting that the dead assemblage can be used to detect differences in gas hydrate seepage integrated over longer time scales. In particular, opportunistic species adapted to oxygen-poor environments, such as Bulimina marginata and Bolivina albatrossi, could indicate alternation between periods of enhanced seep activity and quiescent episodes in different pockmark settings.

\section{Acknowledgements}

We thank the crew and the scientific team of the RV "Pourquoi Pas?" (GUINECO-MeBo Cruise aboard, November 2011). This cruise was supervised by Nabil Sultan (Ifremer EDROME, LES). We thank him and Livio Ruffine for their help during draft construction. Arnold van Dijk (Utrecht Univeristy) is thanked for technical support during foraminiferal isotope measurement. This study was supported by the French program LEFE-CYBER 
(CNRS) under the project name "PROCOS" "PROxies calibration in COld Seep based on living and fossilising meiofauna", by the ANR (Agence Nationale de Recherche) through the Institut Carnot, IFREMER EDROME contract, and by the IFREMER "Aléas" project (PJ2205). The second author would like to thank Darwin Center for Biogeoscience for funding during the project. We thank the three reviewers and Andy Gooday (associate editor) for their relevant comments on the draft.

\section{References}

Akimoto, K., Tanaka, T., Hattori, M., Hotta, H., 1994. Recent benthic foraminiferal assemblages from the cold seep communities - a contribution to the methane gas indicator. In: Tsuchi R. (Ed.), Pacific Neogene Events in Time and Space. University of Tokyo Press, Tokyo, pp.11-25.

Aloisi, G., Pierre, C., Rouchy, J.M., Foucher, J.P., Woodside, J., the MEDINAUT Scientific Party, 2000. Methane-related authigenic carbonates of eastern Mediterranean Sea mud volcanoes and their possible relation to gas hydrate destabilisation. Earth Planetary Science Letters, 184, 321-338.

Altenbach, A. V., Lutze, G. F., Schiebel, R., Schönfeld, J., 2003. Impact of interrelated and interdependant ecological controls on benthic foraminifera: an example from the Gulf of Guinea. Palaeogeography, Palaeoclimatology, Palaeoecology, 197, 213-218.

Barbieri, R., Panieri, G., 2004. How are benthic foraminiferal fauna influenced by cold seep? Evidence from the Miocene of Italy. Palaeogeography, Palaeoclimatology, Palaeoecology, $204,255-275$.

Barnett, P. R. O., Watson, J., Connely, D., 1984. A multiple corer for taking virtually undisturbed sample from shelf, bathyal and abyssal sediments. Oceanologica Acta, 7, 399-408 
Bayon, G., Pierre, C., Etoubleau, J., Voisset, M., Cauquil, E., Marsset, T., Sultan, N., Le Drezen, E., Fouquet, Y., 2007. Sr/Ca and $\mathrm{Mg} / \mathrm{Ca}$ ratios in Niger Delta sediments: implications for authigenic carbonate genesis in cold seep environments. Marine Geology, 241, 93-109. Bayon, G., Birot, D., Ruffine, L., Caprais, J.-C., Ponzevera, E., Bollinger, C., Donval, J.-P., Charlou, J.-L., Voisset, M., Grimaud, S., 2011. Evidence for intense REE scavenging at cold seeps from the Niger Delta margin. Earth and Planetary Science Letters, 312, 443-452.

Bernhard, J. M., 2000. Distinguishing live from dead foraminifera: methods review and proper applications. Micropaleontology, 46, 38-46.

Bernhard, J. M., Buck, K. R., Barry, J. P., 2001. Monterey Bay cold-seep biota: Assemblages, abundance, and ultrastructure of living foraminifera. Deep-Sea Research I, 48, 2233-2249.

Bernhard, J. M., Martin, J. B., Rathburn, A., E., 2010. Combined carbonate carbon isotopic and cellular ultrastructural studies of individual benthic foraminifera: 2. Toward an understanding of apparent disequilibrium in hydrocarbon seeps. Paleoceanography, 25, PA4206, doi:10.1029/2010PA001930.

Borowski, W. S., Paull, C. K., Ussler, III, W., 1999. Global and local variations of interstitial sulphate gradients in deep-water, continental margin sediments: sensitivity to underlying methane and gas hydrates. Marine Geology, 159, 131-154.

Brooks, J. M., Bryant, W. R., Bernard, B. B., Cameron, N. R., 2000. The nature of gas hydrates on the Nigerian continental slope in Gas Hydrates: Challenges for the Future, edited by Holder G. D. and Bishnoi P. R., vol. 912, New York Academy of Sciences, New York, pp. 76-93.

Burton, E. A., 1993. Controls on marine carbonate cement mineralogy: review and reassessment. Chemical Geology, 105, 163-179. 
Campbell, K. A., 2006. Hydrocarbon seep and hydrothermal vent paleoenvironments and paleontology: Past developments and future research directions. Palaeogeography, Palaeoclimatology, Palaeoecology, 232, 362-407.

Capone, K. A., Dowd, S. E., Stamatas, G.N., Nikolovski, J. 2011. Diversity of the human skin microbiome early in life. Journal of Investigative Dermatology 131(10), 2026-2032.

Caralp, M. H., 1989. Abundance of Bulimina exilis and Melonis barleeanum: relationship to the quality of marine organic matter. Geo-Marine Letters 9, 37- 43.

Corliss, B. H., Emerson, S., 1990. Distribution of Rose Bengal stained deep-sea benthic foraminifera from the Nova Scotia continental margin and Gulf of Maine, Deep-Sea Research I, 37, 381-400.

Corredor, F., Shaw, J. H., Bilotti, F., 2005. Structural styles in the deep-water fold and thrust belts of the Niger Delta. AAPG Bulletin 89 (6), 753-780.

Damuth, J. E., 1994, Neogene gravity tectonics and depositional processes on the deep Niger delta continental margin, Marine and Petroleum Geology, 11(3), 320-346.

DeSantis, T. Z., Hugenholtz, P., Larsen, N., Rojas, M., Brodie, E.L., Keller, K., Huber, T., Dalevi, D., Hu, P., Andersen, G.L., 2006. Greengenes, a chimera-checked 16S rRNA gene database and workbench compatible with ARB. Applied Environmental Microbiology 72(7), 5069-5072.

De Stigter, H. C., van der Zwaan, G. J., Langone, L., 1999. Differential rates of benthic foraminiferal test production in surface and subsurface sediment habitats in the southern Adriatic Sea. Palaeogeography, Palaeoclimatology, Palaeoecology, 149, 67-88.

Dowd, S. E., Callaway, T. R., Wolcott, R.D., Sun, Y., McKeehan, T., Hagevoort, R.G., Edrington, T.S., 2008a.. Evaluation of the bacterial diversity in the feces of cattle using 16S rDNA bacterial tag-encoded FLX amplicon pyrosequencing (bTEFAP). BMC Microbiology, 8: 125. 
Dowd, S. E., Sun, Y., Wolcott, R.D., Domingo, A., Carroll, J.A., 2008b. Bacterial tagencoded FLX amplicon pyrosequencing (bTEFAP) for microbiome studies: bacterial diversity in the ileum of newly weaned Salmonella-infected pigs. Foodborne Pathogens and Disease, 5(4), 459-472.

Dowd, S. E., Delton Hanson, J., Rees, E. Wolcott, R.D. Zischau, A.M. Sun, Y. White, J. Smith, D.M., Kennedy, J., Jones, C.E., 2011. Survey of fungi and yeast in polymicrobial infections in chronic wounds. Journal of Wound Care, 20(1), 40-47.

Duchemin, G., Fontanier, C., Jorissen, F. J., Barras, C., Griveaud, C., 2007. Living smallsized $(63-150 \mu \mathrm{m})$ foraminifera from mid-shelf to mid-slope environments in the Bay of Biscay. Journal of Foraminiferal Research, 37, 12-32.

Duros, P., Fontanier, C., Metzger, E., Pusccedu, A., Cesbron, F., de Stigter, H.C., Bianchelli, S., Danovaro, R., Jorissen, F. J., 2011. Live (stained) benthic foraminifera in the Whittard Canyon, Celtic margin (NE Atlantic). Deep-Sea Research part-I, 58, 128-146.

Duros, P., Fontanier, C., de Stigter, H. C., Cesbron, F., Metzger, E. and Jorissen, F. J., 2012. Live and dead benthic foraminiferal faunas from Whittard Canyon (NE Atlantic): Focus on taphonomic processes and paleo-environmental applications. Marine Micropaleontology, 94, $25-44$.

Duros, P., Fontanier, C., Metzger, E., Cesbron, F., Deflandre, B., Schmidt, S., Buscail, R., Zaragosi, S., Kerhervé, P., Rigaud, S., Jorissen F. J., 2013. Live (stained) benthic foraminifera from the Cap-Ferret Canyon (Bay of Biscay, NE Atlantic): a comparison between the canyon axis and the surrounding areas. Deep-Sea Research part-I, 74, 98-114.

Duros, P., Jorissen, F. J., Cesbron, F., Zaragosi, S., Schmidt, S., Fontanier C., 2014, Study of benthic foraminiferal thanatocoenoses from the Cap-Ferret Canyon area (NE Atlantic): A complex interplay between hydro-sedimentary and biological processes. In press. Deep-Sea Research part-II. 
Eberwein, A., Mackensen, A., 2006. Regional primary productivity differences off Morocco (NW-Africa) recorded by modern benthic foraminifera and their stable carbon isotopic composition. Deep-sea Research part-I, 53, 1379-1405.

Edgar, R. C., 2010. Search and clustering orders of magnitude faster than BLAST. Bioinformatics, 26, 2460-2461.

Eisma, D., Kalf, J., Van der Gaast, S. J., 1978. Suspended matter in the Zaire estuary and adjacent Atlantic Ocean. Netherlands Journal of Sea Research, 12(3/4), 382-406.

Eren, A. M., Zozaya, M., Taylor, C.M., Dowd, S.E., Martin, D.H., Ferris, M.J., 2011. Exploring the diversity of Gardnerella vaginalis in the genitourinary tract microbiota of monogamous couples through subtle nucleotide variation. PLoS One 6(10): e26732.

Fontanier, C., Jorissen, F. J., Licari, L., Alexandre, A., Anschutz, P., Carbonel, P., 2002. Live benthic foraminiferal faunas from the Bay of Biscay: faunal density, composition, and microhabitats, Deep-Sea Research I 49, 751-785.

Fontanier, C., Jorissen, F. J., Chaillou, G., David, C., Anschutz, P., Lafon, V., 2003. Seasonal and interannual variability of benthic foraminiferal faunas at $550 \mathrm{~m}$ depth in the Bay of Biscay, Deep-sea Research I 50, 457-494.

Fontanier, C., Jorissen, F. J., Chaillou, G., Anschutz, P., Grémare, A., Griveaud, C., 2005. Live foraminiferal faunas from a $2800 \mathrm{~m}$ deep lower canyon station from the Bay of Biscay: Faunal response to focusing of refractory organic matter. Deep-Sea Research I, 52, 11891227.

Fontanier, C., Jorissen, F. J., Lansard, B., Mouret, A., Buscail, R., Schmidt, S., Kerhervé, P., Buron, F., Zaragosi, S., Hunault, G., Ernoult, E., Artero, C., Anschutz, P., Rabouille, C., 2008a. Live (stained) foraminiferal faunas from open slope environments separating submarine canyons in the Gulf of Lions (NW Mediterranean): diversity, density and microhabitats. Deep-Sea Research I 55, 1532-1553. 
Fontanier, C., Jorissen, F. J., Geslin, E., Zaragosi, S., Duchemin, G., Laversin, M., Gaultier, M., 2008b. Live and dead foraminiferal faunas from the Saint-Tropez Canyon (Bay of Fréjus): Observations based on in situ and incubated cores. Journal of Foraminiferal Research $38,137-156$.

Fontanier, C., Fabri, M.-C., Buscail, R., Biscara, L., Koho, K., Reichart, G. J., Cossa, D., Galaup, S., Chabaud, G., Pigot, L., 2012. Deep-sea foraminifera from the Cassidaigne Canyon (NW Mediterranean): Assessing the environmental impact of bauxite red mud disposal. Marine Pollution Bulletin, 64, 1895-1910.

Foucher, J. P., Westbrook, G. K., Boetius, A., Ceramicola, S., Dupre, S., Mascle, J., Mienert, J., Pfannkuche, O., Pierre, C., Praeg, D., 2009. Structure and drivers of cold seep ecosystems. Oceanography, 22(1), 92-109.

Friedman, I., O’Neil J. R., 1977. Compilation of stable isotope fractionations factors of geochemical interest (Geological Survey Professional Paper 440-KK). In: Fleischer, M., (Ed.), Data of Geochemistry, Sixth Edition. U.S. Government Printing Office, Washington, DC, pp. 1-12.

Grémare, A., Guttiérrez, D., Anschutz, P., Amouroux, J.-M., Deflandre, B., Vétion, G., 2005. Spatio-temporal changes in totally and enzymatically hydrolysable amino acids of superficial sediments from three contrasted areas: Progress in Oceanography, 65, 89-111.

Grossman, E. L., Ku, T.-L., 1986. Oxygen and carbon isotope fractionation in biogenic aragonite: temperature effects. Chemical Geology (Isotope Geoscience Section), 59, 59-74.

Haas, A., Peckmann, J., Elvert, M., Sahling, H., Bohrmann, G., (2010) Patterns of carbonate authigenesis at the Kouilou pockmarks on the Congo deep-sea fan. Marine Geology, 268, $129-136$.

Hayek, L. E. C., Buzas, M. A., 1997. Surveying Natural Populations. Columbia University Press, New York, 563 p. 
Hayward, B. W., Gregory, M. R., Kennett, J. P. (2011) An extinct foraminifer endemic to hydrocarbon seeps? Geology, 39, 603-605.

Heinz, P., Sommer, S., Pfannkuche, O., Hemleben, C., 2005. Living benthic foraminifera in sediments influenced by gas hydrates at the Cascadia convergent margin, NE Pacific. Marine Ecology Progress Series, 304, 77-89.

Hess, S., Jorissen, F. J., Venet, V., Abu-Zied, R., 2005. Benthic foraminiferal recovery after recent turbidite deposition in CapBreton Canyon (Bay of Biscay). Journal of Foraminiferal Research, 35, 114-129.

Hess, S., Jorissen, F. J., 2009. Distribution patterns of living benthic foraminifera from Cap Breton canyon, Bay of Biscay: faunal response to sediment instability. Deep-Sea Research I $56,1555-1578$.

Hill, T. M., Kennett, J. P., Valentine, D. L., 2004. Isotopic evidence for the incorporation of methane-derived carbon into foraminifera from modern methane seeps, Hydrate Ridge, Northeast Pacific. Geochimica et Cosmochimica Acta, 68, 4419-4627.

Kitazato, H., 1996. Benthic foraminifera associated with cold seepages: Discussion of their faunal characteristics and adaptations. Fossils, 60, 48-52.

Koho, K., Kouwenhoven, T. J., de Stigter, H. C., van der Zwaan, G. J., 2007. Benthic foraminifera in the Nazaré canyon, Portuguese continental margin: sedimentary environments and disturbance. Marine Micropaleontology, 66, p. 27-51.

Koho, K. A., García, R., de Stigter, H. C., Epping, E., Koning, E., Kouwenhoven, T. J., van der Zwaan, G. J., 2008. Sedimentary labile organic carbon and pore water redox control on species distribution of benthic foraminifera: a case study from Lisbon-Setúbal Canyon (southern Portugal). Progress in Oceanography, 79, 55-82. 
Levin, L. A., Mendoza, G. F., 2007. Community structure and nutrition of deep methane-seep macrobenthos from the North Pacific (Aleutian) Margin and the Gulf of Mexico (Florida Escarpment), Marine Ecology, 28,131-151.

Licari, L. N., Schumacher, S., Wenzhöfer, F., Zabel, M., Mackensen, A., 2003. Communities and microhabitats of living benthic foraminifera from the tropical east Atlantic: impact of different productivity regimes. Journal of Foraminiferal Research, 33, 10-31.

Licari, L. N., Mackensen, A., 2005. Benthic foraminifera off West Africa ( $1^{\circ} \mathrm{N}$ to $\left.32^{\circ} \mathrm{S}\right)$ : Do live assemblages from the topmost sediment reliably record environmental variability? Marine Micropaleontology, 55, 205-233.

Lobegeier, M. K., and Sen Gupta, B. K., 2008, Foraminifera of hydrocarbon seeps: Gulf of Mexico: Journal of Foraminiferal Research, 38, 93-116.

Luff, R., Wallmann, K., 2003. Fluid flow, methane fluxes, carbonate precipitation and biogeochemical turnover in gas hydrate-bearing sediments at Hydrate Ridge, Cascadia Margin: numerical modeling and mass balances. Geochimica et Cosmochimica Acta, 67, 3403-3421.

Mackensen, A., Wollenburg, J., Licari, L., 2006. Low $\delta 13 \mathrm{C}$ in tests of live epibenthic and endobenthic foraminifera at a site of active methane seepage. Paleoceanography 21, doi: 10.1029/2005PA001196.

Martin, J. B., Day, S. A., Rathburn, A. E., Perez, M. E., Mahn, C., Gieskes, J., 2004. Relationships between the stable isotopic signatures of living and fossil foraminifera in Monterey Bay, California. Geochemistry, Geophysics, Geosystems 5, Q04004. doi:10.1029/2003GC000629.

Martin, R. A., Nesbitt, E. A., Campbell, K. A., 2007. Carbon stable isotopic composition of benthic foraminifera from Pliocene cold methane seeps, Cascadia accretionary margin. Palaeogeography. Palaeoclimatology. Palaeoecology, 246, 260-277. 
Martin, R. A., Nesbitt, E. A., Campbell, K. A., 2010. The effects of anaerobic methane oxidation on benthic foraminiferal assemblages and stable isotopes on the Hikurangi Margin of eastern New Zealand. Marine Geology, 272, 270-284.

Mayer, L. M., Schick, L. L., Sawyer, T., Plante, C., Jumars, P. A., Self, R. L., 1995. Bioavailable amino acids in sediments: a biomimetic, kinetics-based approach. Limnology and Oceanography, 40, 511-520.

McCorkle, D. C., Corliss, B. H., Farnham, C. A., 1997. Vertical distributions and stable isotopic compositions of live (stained) benthic foraminifera from the North Carolina and California continental margin. Deep-sea Research I, 44, 983-1024.

Murray, J. W., 2006. Ecology and Applications of Benthic Foraminifera. Cambridge University Press, Cambridge, 426 p.

Murray, J. W., Bowser, S. S., 2000. Mortality, protoplasm decay rate, and reliability of staining techniques to recognize "living" foraminifera: a review. Journal of Foraminiferal Research, 30, 66-70.

Neveux, J., Lantoine, F., 1993. Spectrofluorometric assay of chlorophylls and phaeopigments using the least squares approximation technique. Deep-Sea Research I, 40 (9), 1747-1765.

O’Neil, J. R., Clayton, R. N., Mayeda, T. K., 1969. Oxygen isotope fractionation in divalent metal carbonates. Journal of Chemical Physics, 51, 5547-5558.

Panieri, G., 2005. Benthic foraminifera associated with a hydrocarbon seep in the Rockall Trough (NE Atlantic). Geobios, 38 (2), 247-255.

Panieri, G., 2006. Foraminiferal response to an active methane seep environment: A case study from the Adriatic Sea. Marine Micropaleontology, 61, 116-130.

Panieri, G., Camerlenghi, A., Conti, S., Pini, G. A., Cacho, I., 2009. Methane seepages recorded in benthic foraminifera from Miocene seep carbonates, Northern Apennines (Italy). Palaeogeography, Palaeoclimatology, Palaeoecology, 284, 271-282. 
Panieri, G., Camerlenghi, A., Cacho, I., Sanchez Cervera, C., Canals, M., Lafuerza, S., Herrera, G., 2012. Tracing seafloor methane emissions with benthic foraminifera: Results from the Ana submarine landslide (Eivissa Channel, Western Mediterranean Sea). Marine Geology 291-294, 97-112.

Pastor, L., Deflandre, B., Viollier, E., Cathalot, C., Metzger, E., Rabouille, C., Escoubeyrou, K., Lloret, E., Pruski, A. M., Vétion, G., Desmalades, M., Buscail, R., Grémare, A., 2011. Influence of the organic matter composition on benthic oxygen demand in the Rhône River prodelta (NW Mediterranean Sea). Continental Shelf Research, 31, 1008-1019.

Rathburn, A. E., Levin, L. A., Held, Z., Lohmann, K. C., 2000. Benthic foraminifera associated with cold methane seeps on the northern California margin: Ecology and stable isotopic composition. Marine Micropaleontology, 38, 247-266.

Rathburn, A. E., Pérez, M. E., Martin, J. B., Day, S. A., Mahn, C., Gieskes, J., Ziebis, W., Williams, D., Bahls, A., 2003. Relationships between the distribution and stable isotopic composition of living benthic foraminifera and cold methane seep biogeochemistry in Monterey Bay, California. Geochemistry, Geophysics, Geosystems, doi:10.1029/2003GC000595.

Riboulot, V., Cattaneo, A., Berne, S., Schneider, R. R., Voisset, M., Imbert, P., Grimaud, S., 2012. Geometry and chronology of late Quaternary depositional sequences in the Eastern Niger Submarine Delta. Marine Geology, 319, 1-20.

Rongemaille, E., Bayon, G., Pierre, C., Bollinger, C., Chu, N. C., Favreau, E., Fouquet, Y., Riboulot, V., Voisset, M., 2011. Rare earth elements in cold seep carbonates from the Niger Delta. Chemical Geology, 286, 196-206.

Ruffine, L., Caprais, J.-C., Bayon, G., Riboulot, V., Donval, J.-P., Etoubleau, J., Birot, D., Pignet, P., Rongemaille, E., Chazallon, B., Grimaud, S., Adamy, J., Charlou, J.-L., Voisset, 
M., 2013. Investigation on the geochemical dynamics of a hydrate-bearing pockmark in the Niger Delta. Marine and Petroleum Geology, 43, 297-309.

Sahling, H., Rickert, D., Linke, P., Suess, E., Lee, R. W., 2002. Community structure at ges hydrate deposits at the Cascadia convergent margin, NE Pacific. Marine Ecology Progress Series, 231, 121-138.

Schiebel, R., 1992. Rezente benthische Foraminiferen in Sedimenten des Schelfes und des oberen Kontinentalhanges im Golf von Guinea (Westafrika). Berichte-GeologischPaläontologisches Institut der Universität Kiel, 51. 179 pp.

Schlitzer, R., 2013. Ocean Data View, http://odv.awi.de.

Schmiedl, G., Mackensen, A., Müller, P. J., 1997. Recent benthic foraminifera from the eastern South Atlantic Ocean: dependence of food supply and water masses. Marine Micropaleontology, 32, 249- 287.

Schönfeld, J, Alve, E, Geslin, E, Jorissen, F, Korsun, S, Spezzaferri, S, group motF (2012) The FOBIMO (FOraminiferal BIo-MOnitoring) initiative--Towards a standardised protocol for soft-bottom benthic foraminiferal monitoring studies Marine Micropaleontology, 94-95, 1-13

Sen Gupta, B. K., Machain-Castillo, M. L., 1993. Benthic foraminifera in oxygen-poor habitats. Marine Micropaleontology, 20, 183-202.

Sen Gupta, B. K., Aharon, P., 1994. Benthic foraminifera of bathyal hydrocarbon vents of the Gulf of Mexico: Initial Report on communities and stable isotopes. Geo-Marine Letters, 14, 88-96.

Sen Gupta, B. K., Platon, E., Bernhard, J. M., Aharon, P., 1997. Foraminiferal colonization of hydrocarbon-seep Bacterial mats and underlying sediment, Gulf of Mexico slope. Journal of Foraminiferal Research, 27, 292-300. 
Sen Gupta, G. K., Smith, L. E., Logegeier, M. K., 2007. Attachment of Foraminifera to vestimentiferan tubeworms at cold seeps: Refuge from seafloor hypoxia and sulfide toxicity. Marine Micropaleontogy, 62, 1-6.

Sibuet M., Olu, K., 1998. Biogeography, biodiversity and fluid dependence of deep-sea coldseep communities at active and passive margins. Deep-Sea Research, 45, 517-567.

Soltwedel, T., 1997. Meiobenthos distribution pattern in the tropical East Atlantic: Indication for fractioned sedimentation of organic matter to the sea floor? Marine Biology, 129, 747756.

Sultan, N., Voisset, M., Marsset, T., Vernant, A. M., Cauquil, E., Colliat, J. L., Curinier, V., 2007. Detection of free gas and gas hydrate based on 3D seismic data and cone penetration testing: An example from the Nigerian Continental Slope, Marine Geology, 240(1-4), 235255.

Sultan, N., Marsset, B., Ker, S., Marsset, T., Voisset, M., Vernant, A. M., Bayon, G., Cauquil, E., Adamy, J., Colliat, J. L., Drapeau, D., 2010. Hydrate dissolution as a potential mechanism for pockmark formation in the Niger delta. Journal of Geophysical Research, 115, B08101, doi : 10.1029/2010JB007453.

Sultan, N., Riboulot, V., Ker, S., Marsset, B., Geli, L., Tary, J.B., Klingelhoefer, F., Voisset, M., Lanfumey, V., Colliat, J.L., Adamy, J., Grimaud, S., 2011. Dynamics of fault-fluidhydrate system around a shale-cored anticline in deepwater Nigeria. Journal of Geophysical Research: Solid Earth, 116.

Sultan, N., Bohrmann, G., Ruffine, L., Pape, T., Riboulot, V., Colliat, J.-L., De Prunelé, A., Dennielou, B., Garziglia, S., Himmler, T., Marsset, T., Peters, C.A., Rabiu, A., Wei, J., 2014. Pockmark formation and evolution in deep water Nigeria: Rapid hydrate growth versus slow hydrate dissolution. Journal of Geophysical Research: Solid Earth, 119, 2679-2694. 
Swanson, K. S., Dowd, S. E., Suchodolski, J.S., Middelbos, I.S., Vester, B.M., Barry, K.A., Nelson, K.E., Torralba, M., Henrissat, B., Coutinho, P.M., Cann, I.K., White, B.A. Fahey Jr., G.C., 2011. Phylogenetic and gene-centric metagenomics of the canine intestinal microbiome reveals similarities with humans and mice. The ISME Journal, 5(4), 639-649.

Teichert, B. M. A., Torres, M. E., Bohrmann, G., Eisenhauer, A., 2005. Fluid sources, fluid pathways and diagenetic reactions across an accretionary prism revealed by $\mathrm{Sr}$ and $\mathrm{B}$ geochemistry. Earth and Planetary Science Letters, 239 (1-2), 106-121.

Timm, S., 1992. Rezente Tiefsee-Benthosforaminiferen aus Oberflächensedimenten des Golfes von Guinea (Westafrika)-Taxonomie, Verbreitung, Ökologie und Korngrögenfraktionen. Berichte-Reports, Geologisches und Paläontologisches Institut der Universität Kiel 59, 192 pp.

Torres, M. E., Mix, A. C., Kinports, K., Haley, B., Klinkhammer, G. P., McManus, J., de Angelis, M. A., 2003. Is methane venting at the seafloor recorded by $\delta^{13} \mathrm{C}$ of benthic foraminifera shells? Paleoceanography, 18, doi:10.1029/2002PA000824.

Torres, M. E., Martin, R. A., Klinkhammer, G. P., Nesbitt, E. A., 2010, Post depositional alteration of foraminiferal shells in cold seep settings: New insights from flow-through timeresolved analyses of biogenic and inorganic seep carbonates. Earth and Planetary Science Letters, 299, 10-22.

Van Bennekom, A. J., Berger, G. W., Helder, W., De Vries R. T. P., 1978. Nutrient distribution in the Zaire estuary and river plume. Netherlands Journal of Sea Research, $12(3 / 4), 296-323$.

Walton, W. R., 1952. Techniques for recognition of living Foraminifera. Contributions from the Cushman Foundation for Foraminiferal Research, 3, 56-60. 
Wiedicke, M., Weiss, W., 2006. Stable carbon isotope records of carbonates tracing fossil seep activity off Indonesia. Geochemistry, Geophysics, Geosystems, 7, Q11009, doi:10.1029/2006GC001292. 


\section{Figure captions}

Fig. 1 Study area with the location of the 4 investigated sites and their position in the pockmark field (Deep-Water Niger delta, Gulf of Guinea) (map modified from Sultan et al., 2010).

Fig. 2 SEM photographs of dominant foraminiferal species. A-B. Living (stained) Bolivina albatrossi (GMMC-01, 0-0.5 cm interval). C. Living (stained) Ceratobulimina contraria (GMMC-03, 4-5 cm interval). D. Living (stained) Uvigerina peregrina (GMMC-03, 2-3 cm interval). E-F. Living (stained) Melonis barleeanus (GMMC-03, 2-3 and 3-4 cm intervals). GH. Altered (unstained) Ceratobulimina contraria (GMMC-01, 4-5 cm interval) and detail of aragonitic overgrowth covering the foraminiferal test. I. Severely altered (unstained) Ceratobulimina contraria (GMMC-02, 4-5 cm interval). J-K. Altered (unstained and broken) Ceratobulimina contraria (GMMC-01, 4-5 cm interval) and detail of foraminiferal test.

Fig. 3 Photographs of two carbonate mudclasts. A. Botryoidal-like concretion from the 2-3 $\mathrm{cm}$ interval at station GMMC-01 (x 7.5); B. Detail of this aggregate (x 20). Note the planktonic foraminifera embedded in the sediments; C. Aggregate from the 2-3 cm interval at station GMMC-01 (x 12.5); D. Detail of the concretion ( $\mathrm{x}$ 32). Note all planktonic foraminifera embedded in sediments.

Fig. 4 SEM photographs of a mudclast from the $2-3 \mathrm{~cm}$ interval at station GMMC-02. A. General view with bar scale $(3 \mathrm{~mm})$. B-D. Detail of the surface with bar scales representing $100 \mu \mathrm{m}$. Note the acicular aragonite, the porous texture and the biogenic material (foraminiferal tests) cemented by authigenic carbonate. 
Fig. 5 Organic descriptors analyzed at the 4 stations in the surface sediments $(0-3 \mathrm{~cm})$. Organic content (TOC in \% DW), C/N atomic ratio, amino acids (EHAA and THAA), and bio-availability are presented in the upper pannels. Content in chlorophyllic pigment (i.e. Chl a) and $[\mathrm{Chl} a /(\mathrm{Chl} a+$ Pheo $a)]$ ratios (i.e., Freshness index) are shown in the lower panels. Vertical bars are standard deviations.

Fig. 6 Bacterial community composition. A. Relative abundance of sequences affiliated to dominant genera (relative abundance $>5 \%$ ) at stations GMMC 01 and GMMC 02 (pockmark A), GMMC 03 (pockmark B) and GMMC 04 (reference station). Data for all sediment intervals $(0-1 \mathrm{~cm}, 1-2 \mathrm{~cm}, 2-3 \mathrm{~cm})$ are illustrated ; B. Relative abundance of sequences affiliated to sulphur-oxidizing bacteria (SOB), sulphate reducing bacteria (SOB) and methanotrophs (MT) representing more than $1 \%$ of the relative abundance in the samples. Others include all the sequences not affiliated to the three functional groups indicated or representing less than $1 \%$ of the relative abundance.

Fig. 7 Foraminiferal composition of living (stained) faunas at the 4 stations. Only species with a relative abundance of $>5 \%$ at one site are shown.

Fig. 8 Composition of dead foraminiferal faunas at the 4 stations. Only species with a relative abundance of $>5 \%$ at one site are shown. Each pie chart is based on the mean values of both 2-3 $\mathrm{cm}$ and 4-5 $\mathrm{cm}$ sediment intervals.

Fig. 9 Q-mode Principal Component Analysis on the 8 sediment intervals (both sediment intervals 2-3 cm and $4-5 \mathrm{~cm}$ per station), based on species contribution $2.5 \%$ or more of the 
assemblage in at least one sediment interval (including 17 species) at the 4 stations. Dashed and dotted lines regroup samples from the same station.

Fig. 10 The average isotopic composition of benthic foraminifera (Bolivina albatrossi, Ceratobulimina contraria, Melonis barleeanus and Uvigerina peregrina) at stations GMMC01 (black circles) GMMC-02 (grey squares) GMMC-03 (white triangles) and GMMC-04 (black diamonds). Dashed lines correspond with $\delta^{18} \mathrm{O}_{\text {e.c. }}$ (for B. albatrossi, M. barleeanus and U. peregrina) and $\delta^{18} \mathrm{O}$ of biogenic aragonite (for C. contraria). Left: data on living (RoseBengal) stained specimens. Right: data on dead (non-stained) specimens. Note both $\delta^{13} \mathrm{C}$ and $\delta^{18} \mathrm{O}$ scale bars vary between species. Error bars represent standard deviation of averages.

Fig. 11 The averaged isotopic composition of Ceratobulimina contraria (altered specimens) and authigenic carbonate mudclasts from station GMMC-02 only. Dashed lines correspond with $\delta^{18} \mathrm{O}_{\text {e.c. }}$ and $\delta^{18} \mathrm{O}$ of biogenic aragonite. Isotope data for living (stained) and dead (wellpreserved) C. contraria are included for comparison.

\section{Table captions}

Table 1 Coordinates and depth of the 4 stations sampled during the GUINECO-MeBo cruise (November 2011). Bottom water salinity (BWS), temperature (BWT) and oxygenation (BWO) are approximate values from eWOCE database (Schlitzer, 2013) and Bayon et al. (2011). "Environmental setting" is described according to nomenclature of Sultan et al. (2010). 
Table 2 Mineralogical composition of surface sediments determined at the 4 stations by X-ray powder diffraction (3 sediment intervals at each site)

Table 3 Diversity Indices (Standing stocks, $S, H^{\prime}$, E, Berger-Parker, E $\left(\mathrm{S}_{100}\right)$ ) calculated for the living (stained) foraminiferal faunas at the 4 stations. Standing stocks are expressed as the number of individuals per $100 \mathrm{~cm}^{2} . \mathrm{S}$ and $\mathrm{E}\left(\mathrm{S}_{100}\right)$ are expressed as the number of species.

Table 4 Diversity Indices (Counted foraminifera, $\mathrm{S}, \mathrm{H}^{\prime}, \mathrm{E}$, Berger-Parker, $\mathrm{E}\left(\mathrm{S}_{100}\right)$ ) calculated for the dead foraminiferal faunas from both sediment intervals $(2-3 \mathrm{~cm}$ and $4-5 \mathrm{~cm})$ at the 4 stations. $\mathrm{S}$ and $\mathrm{E}\left(\mathrm{S}_{100}\right)$ are expressed as the number of species.

Table 5 Stable isotope values $\left(\delta^{13} \mathrm{C}\right.$ and $\left.\delta^{18} \mathrm{O}\right)$ of living (Rose Bengal stained) and dead foraminifera from the 4 stations. The number of specimens and their related weights are indicated. In some cases, foraminifera were broken due to large sample size. In these cases, the weight of the measured sample is given separately in brackets. 
Table 1

\begin{tabular}{|c|c|c|c|c|c|c|c|c|}
\hline $\begin{array}{l}\text { Station } \\
\text { Name }\end{array}$ & Date & $\begin{array}{l}\text { Latitude } \\
\text { (N) }\end{array}$ & $\begin{array}{l}\text { Longitude } \\
\text { (E) }\end{array}$ & $\begin{array}{l}\text { Depth } \\
\text { (m) }\end{array}$ & $\begin{array}{l}\text { BWT } \\
\left({ }^{\circ} \mathrm{C}\right)\end{array}$ & BWS & $\begin{array}{c}\text { BWO } \\
(\mu \mathrm{mol} / \mathrm{L})\end{array}$ & $\begin{array}{c}\text { Environmental } \\
\text { setting }\end{array}$ \\
\hline \multicolumn{3}{|c|}{$25 / 11 / 20$} & \multicolumn{6}{|c|}{$\sim 34$. } \\
\hline \multirow[t]{2}{*}{ GMMC-01 } & 11 & $3^{\circ} 15.046$ & $6^{\circ} 41.927$ & 1143 & $\sim 5$ & 8 & $\sim 180$ & "Pockmark A" \\
\hline & $25 / 11 / 20$ & & \multicolumn{6}{|c|}{$\sim 34}$. \\
\hline \multirow[t]{2}{*}{ GMMC-02 } & 11 & $3^{\circ} 14.997$ & $6^{\circ} 41.925$ & 1144 & $\sim 5$ & 8 & $\sim 180$ & "Pockmark A" \\
\hline & $25 / 11 / 20$ & & \multicolumn{6}{|c|}{$\sim 34$. } \\
\hline \multirow[t]{2}{*}{ GMMC-03 } & 11 & $3^{\circ} 14.475$ & $6^{\circ} 41.805$ & 1220 & $\sim 5$ & 8 & $\sim 180$ & "Pockmark B" \\
\hline & $25 / 11 / 20$ & & & & & $\sim 34$. & & Non-seep \\
\hline GMMC-04 & 11 & $3^{\circ} 15.099$ & $6^{\circ} 41.802$ & 1141 & $\sim 5$ & 8 & $\sim 180$ & Reference \\
\hline
\end{tabular}

Table 2

\begin{tabular}{|c|c|c|c|c|c|c|c|c|c|c|c|c|}
\hline & & MMC- & & & IMC- & & & VMC & & & AMC- & \\
\hline & $0-1$ & $1-2$ & $2-3$ & & $1-2$ & $2-3$ & $0-1$ & $1-2$ & & & $1-2$ & $2-3$ \\
\hline & $\mathrm{cm}$ & $\mathrm{cm}$ & $\mathrm{cm}$ & $0-1 \mathrm{~cm}$ & $\mathrm{~cm}$ & $\mathrm{~cm}$ & $\mathrm{~cm}$ & $\mathrm{~cm}$ & $2-3 \mathrm{~cm}$ & $0-1 \mathrm{~cm}$ & $\mathrm{~cm}$ & $\mathrm{~cm}$ \\
\hline Kaolinite & $* *$ & $* *$ & $* *$ & $* *$ & $* *$ & $* *$ & $* *$ & $* * *$ & $* * *$ & $* * *$ & $* *$ & $* * *$ \\
\hline Montmorillonite & $* *$ & $*$ & - & & $*$ & $* *$ & & & - & - & & \\
\hline Muscovite & & & & & & & & & & & & \\
\hline (Mica) & - & $*$ & $* *$ & $* *$ & $* *$ & $*$ & $* * *$ & $* * *$ & $* * *$ & $* *$ & $* * *$ & $* * *$ \\
\hline Halloysite & & & & & & & & & & $*$ & - & $*$ \\
\hline Microcline & & & & & & & & $*$ & $*$ & $* *$ & - & - \\
\hline Calcite & $* * *$ & $* * *$ & $* * *$ & $* * *$ & $* * *$ & $* * *$ & $* * *$ & $* * *$ & $* * *$ & $* * *$ & $* * *$ & $* * *$ \\
\hline Mg-Calcite & $*$ & $*$ & $*$ & $* *$ & $* *$ & $* * *$ & & & & & & \\
\hline Aragonite & $* * *$ & $* * *$ & $* * *$ & $* *$ & $*$ & $* *$ & & & & & & \\
\hline Quartz & $*$ & $*$ & $*$ & $*$ & $* *$ & $*$ & $* * *$ & $* * *$ & $* * *$ & $* * *$ & $* *$ & $* * *$ \\
\hline & - & Rare & $*$ & $\begin{array}{c}\text { Presen } \\
\mathrm{t}\end{array}$ & $* *$ & $\mathrm{Abu}$ & dant & $* * *$ & $\begin{array}{r}V e \\
\text { Abun }\end{array}$ & $\begin{array}{l}\text { ery } \\
\text { ndant }\end{array}$ & & \\
\hline
\end{tabular}

Table 3

\begin{tabular}{|c|c|c|c|c|}
\hline Living Foraminiferal Faunas & GMMC-01 & GMMC-02 & GMMC-03 & GMMC-04 \\
\hline Simple diversity S & 59 & 55 & 52 & 40 \\
\hline Standing stocks (Ind./100 $\mathrm{cm}^{2}$ ) & 362 & 296 & 365 & 169 \\
\hline Shannon Index H' & 3.54 & 3.45 & 3.30 & 3.23 \\
\hline Evenness Index E & 0.58 & 0.57 & 0.52 & 0.63 \\
\hline Berger-Parker Index & 0.15 & 0.13 & 0.13 & 0.12 \\
\hline Rarefaction Index $E\left(S_{100}\right)$ & 41 & 38 & 34 & 36 \\
\hline
\end{tabular}




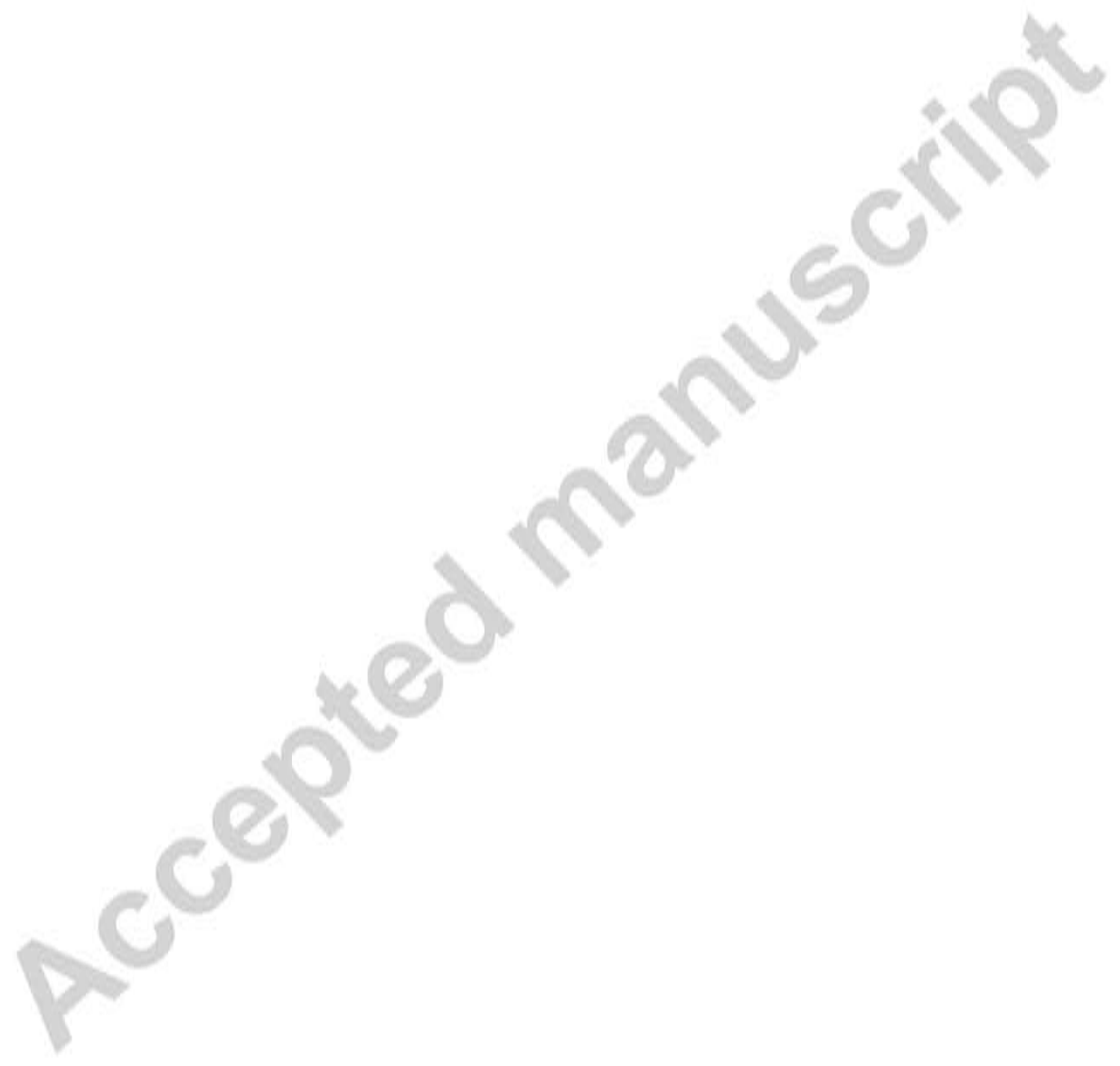


Table 4

\begin{tabular}{|c|c|c|c|c|c|c|c|c|}
\hline Dead Foraminiferal Faunas & \multicolumn{2}{|c|}{ GMMC-01 } & \multicolumn{2}{|c|}{ GMMC-02 } & \multicolumn{2}{|c|}{ GMMC-03 } & \multicolumn{2}{|c|}{ GMMC-04 } \\
\hline Sediment interval & $2-3 \mathrm{~cm}$ & $4-5 \mathrm{~cm}$ & $2-3 \mathrm{~cm}$ & $4-5 \mathrm{~cm}$ & $2-3 \mathrm{~cm}$ & $4-5 \mathrm{~cm}$ & $2-3 \mathrm{~cm}$ & $4-5 \mathrm{~cm}$ \\
\hline Simple diversity S & 33 & 33 & 44 & 43 & 32 & 41 & 53 & 46 \\
\hline Counted foraminifera & 216 & 225 & 261 & 305 & 235 & 345 & 283 & 250 \\
\hline Shannon Index H' & 2.85 & 3.02 & 3.10 & 3.08 & 2.66 & 2.76 & 3.28 & 3.24 \\
\hline Evenness Index E & 0.53 & 0.62 & 0.51 & 0.51 & 0.45 & 0.39 & 0.50 & 0.55 \\
\hline Berger-Parker Index & 0.15 & 0.10 & 0.13 & 0.12 & 0.29 & 0.26 & 0.15 & 0.14 \\
\hline Rarefaction Index $\mathrm{E}\left(\mathrm{S}_{100}\right)$ & 24 & 26 & 30 & 28 & 24 & 24 & 34 & 32 \\
\hline
\end{tabular}

Table 5

\begin{tabular}{|c|c|c|c|c|c|c|}
\hline Station & $\begin{array}{c}\text { Sed. Interval } \\
\mathrm{cm}\end{array}$ & $\begin{array}{c}\delta 13 \mathrm{C} \% \text { o } \\
\text { PDB }\end{array}$ & $\begin{array}{c}\delta 180 \% \text { \% } \\
\text { PDB }\end{array}$ & $\begin{array}{l}\text { Species } \\
\text { Living }\end{array}$ & $\begin{array}{c}\text { No. of } \\
\text { specimens }\end{array}$ & $\begin{array}{c}\text { Weight } \\
\mu \mathrm{g}\end{array}$ \\
\hline GMMC-01 & $0.0-0.5$ & -1.49 & 2.94 & B. albatrossi & 8 & 29 \\
\hline GMMC-01 & $0.5-1.5$ & -1.00 & 2.97 & B. albatrossi & 6 & 21 \\
\hline GMMC-02 & $0.0-1.5$ & -1.28 & 3.00 & B. albatrossi & 7 & 26 \\
\hline GMMC-02 & $2.0-3.0$ & -1.40 & 3.04 & B. albatrossi & 6 & 27 \\
\hline GMMC-03 & $0.0-1.0$ & -1.06 & 3.06 & B. albatrossi & 11 & 39 \\
\hline GMMC-03 & $1.0-1.5$ & -0.95 & 3.07 & B. albatrossi & 9 & 37 \\
\hline GMMC-03 & $1.5-2.0$ & -0.94 & 3.10 & B. albatrossi & 11 & 39 \\
\hline GMMC-04 & $0.0-1.5$ & -1.54 & 1.39 & B. albatrossi & 8 & 31 \\
\hline GMMC-01 & $0.0-0.5$ & 0.71 & 3.71 & C. contraria & 1 & 65 \\
\hline GMMC-01 & $0.5-1.0$ & 0.59 & 3.86 & C. contraria & 1 & 51 \\
\hline GMMC-01 & $0.0-0.5$ & 0.53 & 3.72 & C. contraria & 4 & 46 \\
\hline GMMC-01 & $0.5-1.0$ & 0.91 & 3.88 & C. contraria & 1 & 36 \\
\hline GMMC-01 & $0.0-4.0$ & 0.98 & 3.77 & C. contraria & 5 & 54 \\
\hline GMMC-01 & $0.0-0.5$ & 0.87 & 3.65 & C. contraria & 1 & 31 \\
\hline GMMC-02 & $2.0-3.0$ & 0.46 & 3.84 & C. contraria & 1 & 70 \\
\hline GMMC-02 & $3.0-5.0$ & 0.47 & 3.82 & C. contraria & 1 & 61 \\
\hline GMMC-02 & $0.0-0.5$ & 0.15 & 3.93 & C. contraria & 1 & 53 \\
\hline GMMC-02 & $0.0-1.0$ & 0.53 & 3.75 & C. contraria & 3 & 42 \\
\hline GMMC-02 & $1.0-1.5$ & 0.57 & 3.69 & C. contraria & 1 & 24 \\
\hline GMMC-02 & $0.5-1.0$ & 0.64 & 3.64 & C. contraria & 1 & 60 \\
\hline GMMC-02 & $2.0-3.0$ & 0.24 & 3.65 & C. contraria & 1 & 47 \\
\hline GMMC-02 & $0.5-1.5$ & 0.64 & 3.69 & C. contraria & 2 & 31 \\
\hline GMMC-02 & $0.5-3.0$ & 0.64 & 3.65 & C. contraria & 8 & 31 \\
\hline GMMC-02 & $0.0-0.5$ & 0.50 & 3.69 & C. contraria & 1 & 31 \\
\hline GMMC-03 & $1.0-4.0$ & 2.05 & 5.54 & C. contraria & 4 & 45 \\
\hline
\end{tabular}




\begin{tabular}{|c|c|c|c|c|c|c|}
\hline GMMC-03 & $0.5-1.0$ & 1.34 & 3.80 & C. contraria & 1 & 40 \\
\hline GMMC-03 & $0.0-0.5$ & 1.44 & 3.70 & C. contraria & 4 & 22 \\
\hline GMMC-03 & $0.5-1.0$ & 1.39 & 3.72 & C. contraria & 3 & 38 \\
\hline GMMC-04 & $0.0-0.5$ & 1.98 & 3.87 & C. contraria & 1 & 52 \\
\hline GMMC-04 & $1.0-1.5$ & 1.32 & 3.92 & C. contraria & 1 & 47 \\
\hline GMMC-04 & $1.0-1.5$ & 1.42 & 3.74 & C. contraria & 1 & 32 \\
\hline GMMC-04 & $0.0-1.0$ & 1.59 & 3.78 & C. contraria & 4 & 34 \\
\hline GMMC-04 & $1.0-1.5$ & 1.54 & 3.73 & C. contraria & 2 & 26 \\
\hline GMMC-01 & $0.5-1.0$ & -1.67 & 2.54 & M. barleeanus & 3 & 61 \\
\hline GMMC-01 & $0.0-0.5$ & -1.42 & 2.57 & M. barleeanus & 2 & 58 \\
\hline GMMC-01 & $0.0-0.5$ & -1.71 & 2.51 & M. barleeanus & 2 & 51 \\
\hline GMMC-01 & $0.0-0.5$ & -1.63 & 2.56 & M. barleeanus & 2 & 50 \\
\hline GMMC-01 & $0.5-1.0$ & -1.61 & 2.56 & M. barleeanus & 1 & 42 \\
\hline GMMC-01 & $0.5-1.0$ & -1.68 & 2.62 & M. barleeanus & 1 & 42 \\
\hline GMMC-01 & $0.5-1.0$ & -1.36 & 2.80 & M. barleeanus & 1 & 42 \\
\hline GMMC-01 & $0.5-1.0$ & -1.71 & 2.61 & M. barleeanus & 2 & 35 \\
\hline GMMC-01 & $0.5-1.0$ & -1.78 & 2.56 & M. barleeanus & 6 & 35 \\
\hline GMMC-01 & $0.5-1.0$ & -1.58 & 2.52 & M. barleeanus & 2 & 34 \\
\hline GMMC-01 & $0.0-0.5$ & -1.63 & 2.58 & M. barleeanus & 1 & 32 \\
\hline GMMC-01 & $0.5-1.0$ & -1.59 & 2.68 & M. barleeanus & 1 & 32 \\
\hline GMMC-01 & $0.5-1.0$ & -1.47 & 2.62 & M. barleeanus & 1 & 32 \\
\hline GMMC-01 & $1.5-2.0$ & -1.55 & 2.76 & M. barleeanus & 1 & 33 \\
\hline GMMC-01 & $1.5-2.0$ & -1.35 & 2.67 & M. barleeanus & 1 & 31 \\
\hline GMMC-01 & $1.0-2.0$ & -1.76 & 2.58 & M. barleeanus & 2 & 28 \\
\hline GMMC-01 & $0.0-0.5$ & -1.46 & 3.18 & M. barleeanus & 1 & 21 \\
\hline GMMC-01 & $2.0-4.0$ & -1.39 & 2.66 & M. barleeanus & 3 & 21 \\
\hline GMMC-01 & $0.5-2.0$ & -1.64 & 2.64 & M. barleeanus & 3 & 30 \\
\hline GMMC-01 & $0.5-1.0$ & -1.73 & 2.75 & M. barleeanus & 1 & 32 \\
\hline GMMC-02 & $2.0-3.0$ & -1.65 & 2.46 & M. barleeanus & 2 & 68 \\
\hline GMMC-02 & $2.0-3.0$ & -1.99 & 2.56 & M. barleeanus & 1 & 48 \\
\hline GMMC-02 & $3.0-5.0$ & -2.26 & 2.71 & M. barleeanus & 1 & 45 \\
\hline GMMC-02 & $1.5-2.0$ & -1.76 & 2.70 & M. barleeanus & 1 & 39 \\
\hline GMMC-02 & $1.5-2.0$ & -1.82 & 2.64 & M. barleeanus & 1 & 35 \\
\hline GMMC-02 & $2.0-3.0$ & -1.60 & 2.67 & M. barleeanus & 2 & 33 \\
\hline GMMC-02 & $2.0-5.0$ & -1.97 & 2.53 & M. barleeanus & 2 & 35 \\
\hline GMMC-03 & $2.0-3.0$ & -1.19 & 2.58 & M. barleeanus & 4 & 62 \\
\hline GMMC-03 & $0.5-1.0$ & -0.93 & 2.66 & M. barleeanus & 1 & 37 \\
\hline GMMC-03 & $1.0-1.5$ & -1.14 & 2.60 & M. barleeanus & 3 & 51 \\
\hline GMMC-03 & $1.0-1.5$ & -1.21 & 2.57 & M. barleeanus & 2 & 26 \\
\hline GMMC-03 & $1.5-2.0$ & -1.12 & 2.65 & M. barleeanus & 2 & 24 \\
\hline GMMC-03 & $2.0-3.0$ & -1.23 & 2.67 & M. barleeanus & 6 & 42 \\
\hline GMMC-03 & $3.0-4.0$ & -1.25 & 2.55 & M. barleeanus & 1 & 25 \\
\hline GMMC-03 & $3.0-4.0$ & -1.35 & 2.58 & M. barleeanus & 3 & 25 \\
\hline GMMC-04 & $2.0-3.0$ & -1.22 & 2.61 & M. barleeanus & 3 & 40 \\
\hline
\end{tabular}




\begin{tabular}{|c|c|c|c|c|c|c|}
\hline GMMC-04 & $2.0-4.0$ & -1.17 & 2.54 & M. barleeanus & 6 & 34 \\
\hline GMMC-01 & $0.5-1.0$ & -1.16 & 3.11 & $U$. peregrina & 1 & 56 \\
\hline GMMC-01 & $1.0-2.0$ & -1.08 & 3.10 & $U$. peregrina & 1 & 77 (48) \\
\hline GMMC-01 & $1.0-2.0$ & -1.68 & 3.11 & $U$. peregrina & 1 & 41 \\
\hline GMMC-01 & $0.0-0.5$ & -1.54 & 2.92 & $U \cdot$ peregrina & 1 & 23 \\
\hline GMMC-01 & $0.0-0.5$ & -0.61 & 3.00 & U. peregrina & 1 & 24 \\
\hline GMMC-02 & $1.0-1.5$ & -1.36 & 3.13 & $U$. peregrina & 1 & $120(55)$ \\
\hline GMMC-02 & $1.0-2.0$ & -1.50 & 2.98 & $U$. peregrina & 2 & 40 \\
\hline GMMC-02 & $1.0-1.5$ & -1.46 & 3.10 & $U$. peregrina & 1 & $120(51)$ \\
\hline GMMC-03 & $0.0-1.0$ & -0.54 & 3.03 & $U$. peregrina & 3 & 40 \\
\hline GMMC-03 & $0.5-1.0$ & -0.35 & 3.25 & $U$. peregrina & 1 & 49 \\
\hline GMMC-03 & $1.0-1.5$ & 0.12 & 3.83 & $U$. peregrina & 1 & 48 \\
\hline GMMC-03 & $1.0-1.5$ & -0.77 & 3.30 & $U$. peregrina & 1 & 49 \\
\hline GMMC-03 & $0.5-1.0$ & -0.76 & 3.19 & $U$. peregrina & 1 & 35 \\
\hline GMMC-04 & $0.0-1.0$ & -0.14 & 3.06 & $U$. peregrina & 1 & 41 \\
\hline GMMC-04 & $1.5-2.0$ & -0.29 & 3.05 & $U$. peregrina & 1 & $90(40)$ \\
\hline GMMC-04 & $0.0-1.0$ & -0.55 & 2.88 & $U$. peregrina & 2 & 22 \\
\hline
\end{tabular}




\begin{tabular}{|c|c|c|c|c|c|c|}
\hline Station & $\begin{array}{c}\text { Sed. Interval } \\
\mathrm{cm}\end{array}$ & $\begin{array}{c}\delta 13 \mathrm{C} \% \\
\text { PDB }\end{array}$ & $\begin{array}{c}\delta 180 \% \\
\text { PDB }\end{array}$ & $\begin{array}{l}\text { Species } \\
\text { Living }\end{array}$ & $\begin{array}{c}\text { No. of } \\
\text { specimens }\end{array}$ & $\begin{array}{c}\text { Weight } \\
\mu \mathrm{g}\end{array}$ \\
\hline GMMC-01 & $0.0-0.5$ & -1.49 & 2.94 & B. albatrossi & 8 & 29 \\
\hline GMMC-01 & $0.5-1.5$ & -1.00 & 2.97 & B. albatrossi & 6 & 21 \\
\hline GMMC-02 & $0.0-1.5$ & -1.28 & 3.00 & B. albatrossi & 7 & 26 \\
\hline GMMC-02 & $2.0-3.0$ & -1.40 & 3.04 & B. albatrossi & 6 & 27 \\
\hline GMMC-03 & $0.0-1.0$ & -1.06 & 3.06 & B. albatrossi & 11 & 39 \\
\hline GMMC-03 & $1.0-1.5$ & -0.95 & 3.07 & B. albatrossi & 9 & 37 \\
\hline GMMC-03 & $1.5-2.0$ & -0.94 & 3.10 & B. albatrossi & 11 & 39 \\
\hline GMMC-04 & $0.0-1.5$ & -1.54 & 1.39 & B. albatrossi & 8 & 31 \\
\hline GMMC-01 & $0.0-0.5$ & 0.71 & 3.71 & C. contraria & 1 & 65 \\
\hline GMMC-01 & $0.5-1.0$ & 0.59 & 3.86 & C. contraria & 1 & 51 \\
\hline GMMC-01 & $0.0-0.5$ & 0.53 & 3.72 & C. contraria & 4 & 46 \\
\hline GMMC-01 & $0.5-1.0$ & 0.91 & 3.88 & C. contraria & 1 & 36 \\
\hline GMMC-01 & $0.0-4.0$ & 0.98 & 3.77 & C. contraria & 5 & 54 \\
\hline GMMC-01 & $0.0-0.5$ & 0.87 & 3.65 & C. contraria & 1 & 31 \\
\hline GMMC-02 & $2.0-3.0$ & 0.46 & 3.84 & C. contraria & 1 & 70 \\
\hline GMMC-02 & $3.0-5.0$ & 0.47 & 3.82 & C. contraria & 1 & 61 \\
\hline GMMC-02 & $0.0-0.5$ & 0.15 & 3.93 & C. contraria & 1 & 53 \\
\hline GMMC-02 & $0.0-1.0$ & 0.53 & 3.75 & C. contraria & 3 & 42 \\
\hline GMMC-02 & $1.0-1.5$ & 0.57 & 3.69 & C. contraria & 1 & 24 \\
\hline GMMC-02 & $0.5-1.0$ & 0.64 & 3.64 & C. contraria & 1 & 60 \\
\hline GMMC-02 & $2.0-3.0$ & 0.24 & 3.65 & C. contraria & 1 & 47 \\
\hline GMMC-02 & $0.5-1.5$ & 0.64 & 3.69 & C. contraria & 2 & 31 \\
\hline GMMC-02 & $0.5-3.0$ & 0.64 & 3.65 & C. contraria & 8 & 31 \\
\hline GMMC-02 & $0.0-0.5$ & 0.50 & 3.69 & C. contraria & 1 & 31 \\
\hline GMMC-03 & $1.0-4.0$ & 2.05 & 5.54 & C. contraria & 4 & 45 \\
\hline GMMC-03 & $0.5-1.0$ & 1.34 & 3.80 & C. contraria & 1 & 40 \\
\hline GMMC-03 & $0.0-0.5$ & 1.44 & 3.70 & C. contraria & 4 & 22 \\
\hline GMMC-03 & $0.5-1.0$ & 1.39 & 3.72 & C. contraria & 3 & 38 \\
\hline GMMC-04 & $0.0-0.5$ & 1.98 & 3.87 & C. contraria & 1 & 52 \\
\hline GMMC-04 & $1.0-1.5$ & 1.32 & 3.92 & C. contraria & 1 & 47 \\
\hline GMMC-04 & $1.0-1.5$ & 1.42 & 3.74 & C. contraria & 1 & 32 \\
\hline GMMC-04 & $0.0-1.0$ & 1.59 & 3.78 & C. contraria & 4 & 34 \\
\hline GMMC-04 & $1.0-1.5$ & 1.54 & 3.73 & C. contraria & 2 & 26 \\
\hline GMMC-01 & $0.5-1.0$ & -1.67 & 2.54 & M. barleeanus & 3 & 61 \\
\hline GMMC-01 & $0.0-0.5$ & -1.42 & 2.57 & M. barleeanus & 2 & 58 \\
\hline GMMC-01 & $0.0-0.5$ & -1.71 & 2.51 & M. barleeanus & 2 & 51 \\
\hline GMMC-01 & $0.0-0.5$ & -1.63 & 2.56 & M. barleeanus & 2 & 50 \\
\hline GMMC-01 & $0.5-1.0$ & -1.61 & 2.56 & M. barleeanus & 1 & 42 \\
\hline GMMC-01 & $0.5-1.0$ & -1.68 & 2.62 & M. barleeanus & 1 & 42 \\
\hline GMMC-01 & $0.5-1.0$ & -1.36 & 2.80 & M. barleeanus & 1 & 42 \\
\hline GMMC-01 & $0.5-1.0$ & -1.71 & 2.61 & M. barleeanus & 2 & 35 \\
\hline GMMC-01 & $0.5-1.0$ & -1.78 & 2.56 & M. barleeanus & 6 & 35 \\
\hline
\end{tabular}




\begin{tabular}{|c|c|c|c|c|c|c|}
\hline GMMC-01 & $0.5-1.0$ & -1.58 & 2.52 & M. barleeanus & 2 & 34 \\
\hline GMMC-01 & $0.0-0.5$ & -1.63 & 2.58 & M. barleeanus & 1 & 32 \\
\hline GMMC-01 & $0.5-1.0$ & -1.59 & 2.68 & M. barleeanus & 1 & 32 \\
\hline GMMC-01 & $0.5-1.0$ & -1.47 & 2.62 & M. barleeanus & 1 & 32 \\
\hline GMMC-01 & $1.5-2.0$ & -1.55 & 2.76 & M. barleeanus & 1 & 33 \\
\hline GMMC-01 & $1.5-2.0$ & -1.35 & 2.67 & M. barleeanus & 1 & 31 \\
\hline GMMC-01 & $1.0-2.0$ & -1.76 & 2.58 & M. barleeanus & 2 & 28 \\
\hline GMMC-01 & $0.0-0.5$ & -1.46 & 3.18 & M. barleeanus & 1 & 21 \\
\hline GMMC-01 & $2.0-4.0$ & -1.39 & 2.66 & M. barleeanus & 3 & 21 \\
\hline GMMC-01 & $0.5-2.0$ & -1.64 & 2.64 & M. barleeanus & 3 & 30 \\
\hline GMMC-01 & $0.5-1.0$ & -1.73 & 2.75 & M. barleeanus & 1 & 32 \\
\hline GMMC-02 & $2.0-3.0$ & -1.65 & 2.46 & M. barleeanus & 2 & 68 \\
\hline GMMC-02 & $2.0-3.0$ & -1.99 & 2.56 & M. barleeanus & 1 & 48 \\
\hline GMMC-02 & $3.0-5.0$ & -2.26 & 2.71 & M. barleeanus & 1 & 45 \\
\hline GMMC-02 & $1.5-2.0$ & -1.76 & 2.70 & M. barleeanus & 1 & 39 \\
\hline GMMC-02 & $1.5-2.0$ & -1.82 & 2.64 & M. barleeanus & 1 & 35 \\
\hline GMMC-02 & $2.0-3.0$ & -1.60 & 2.67 & M. barleeanus & 2 & 33 \\
\hline GMMC-02 & $2.0-5.0$ & -1.97 & 2.53 & M. barleeanus & 2 & 35 \\
\hline GMMC-03 & $2.0-3.0$ & -1.19 & 2.58 & M. barleeanus & 4 & 62 \\
\hline GMMC-03 & $0.5-1.0$ & -0.93 & 2.66 & M. barleeanus & 1 & 37 \\
\hline GMMC-03 & $1.0-1.5$ & -1.14 & 2.60 & M. barleeanus & 3 & 51 \\
\hline GMMC-03 & $1.0-1.5$ & -1.21 & 2.57 & M. barleeanus & 2 & 26 \\
\hline GMMC-03 & $1.5-2.0$ & -1.12 & 2.65 & M. barleeanus & 2 & 24 \\
\hline GMMC-03 & $2.0-3.0$ & -1.23 & 2.67 & M. barleeanus & 6 & 42 \\
\hline GMMC-03 & $3.0-4.0$ & -1.25 & 2.55 & M. barleeanus & 1 & 25 \\
\hline GMMC-03 & $3.0-4.0$ & -1.35 & 2.58 & M. barleeanus & 3 & 25 \\
\hline GMMC-04 & $2.0-3.0$ & -1.22 & 2.61 & M. barleeanus & 3 & 40 \\
\hline GMMC-04 & $2.0-4.0$ & -1.17 & 2.54 & M. barleeanus & 6 & 34 \\
\hline GMMC-01 & $0.5-1.0$ & -1.16 & 3.11 & $U$. peregrina & 1 & 56 \\
\hline GMMC-01 & $1.0-2.0$ & -1.08 & 3.10 & $U$. peregrina & 1 & 77 (48) \\
\hline GMMC-01 & $1.0-2.0$ & -1.68 & 3.11 & $U$. peregrina & 1 & 41 \\
\hline GMMC-01 & $0.0-0.5$ & -1.54 & 2.92 & $U$. peregrina & 1 & 23 \\
\hline GMMC-01 & $0.0-0.5$ & -0.61 & 3.00 & $U$. peregrina & 1 & 24 \\
\hline GMMC-02 & $1.0-1.5$ & -1.36 & 3.13 & $U \cdot$ peregrina & 1 & $120(55)$ \\
\hline GMMC-02 & $1.0-2.0$ & -1.50 & 2.98 & $U$. peregrina & 2 & 40 \\
\hline GMMC-02 & $1.0-1.5$ & -1.46 & 3.10 & $U$. peregrina & 1 & $120(51)$ \\
\hline GMMC-03 & $0.0-1.0$ & -0.54 & 3.03 & $U \cdot$ peregrina & 3 & 40 \\
\hline GMMC-03 & $0.5-1.0$ & -0.35 & 3.25 & $U$. peregrina & 1 & 49 \\
\hline GMMC-03 & $1.0-1.5$ & 0.12 & 3.83 & $U$. peregrina & 1 & 48 \\
\hline GMMC-03 & $1.0-1.5$ & -0.77 & 3.30 & $U \cdot$ peregrina & 1 & 49 \\
\hline GMMC-03 & $0.5-1.0$ & -0.76 & 3.19 & $U$. peregrina & 1 & 35 \\
\hline GMMC-04 & $0.0-1.0$ & -0.14 & 3.06 & $U$. peregrina & 1 & 41 \\
\hline GMMC-04 & $1.5-2.0$ & -0.29 & 3.05 & $U$. peregrina & 1 & $90(40)$ \\
\hline GMMC-04 & $0.0-1.0$ & -0.55 & 2.88 & U. peregrina & 2 & 22 \\
\hline
\end{tabular}




\section{Highlights}

- We work on living and dead benthic foraminifera sampled in a pockmark field.

- Fossilizing meiobenthos are compared between seep and non-seep sites.

- The $\delta^{13} \mathrm{C}$ signatures of living faunas are depleted in episodically active pockmark.

- In dead faunas, dominant opportunistic species indicate episodic seepage events. 


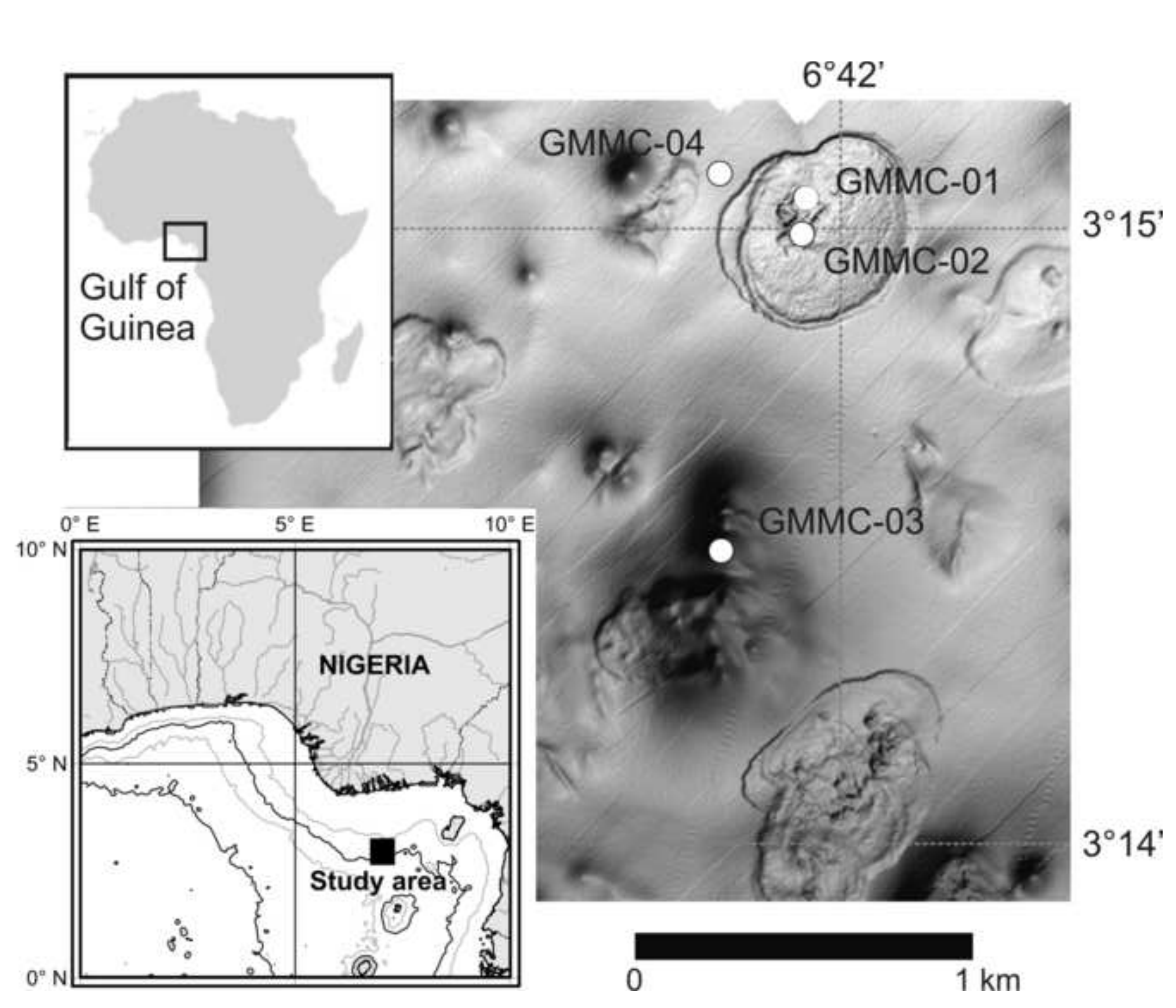

.



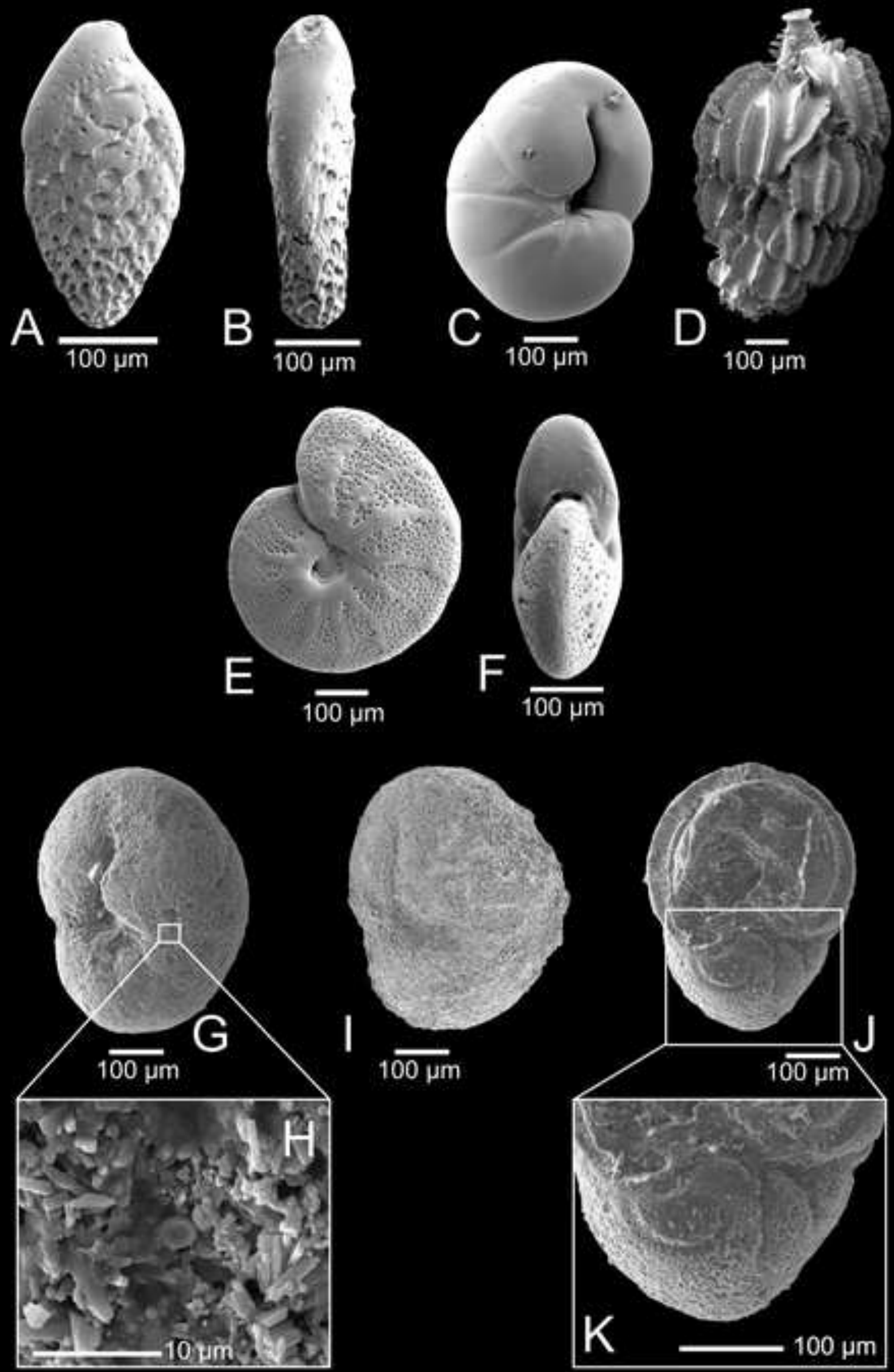

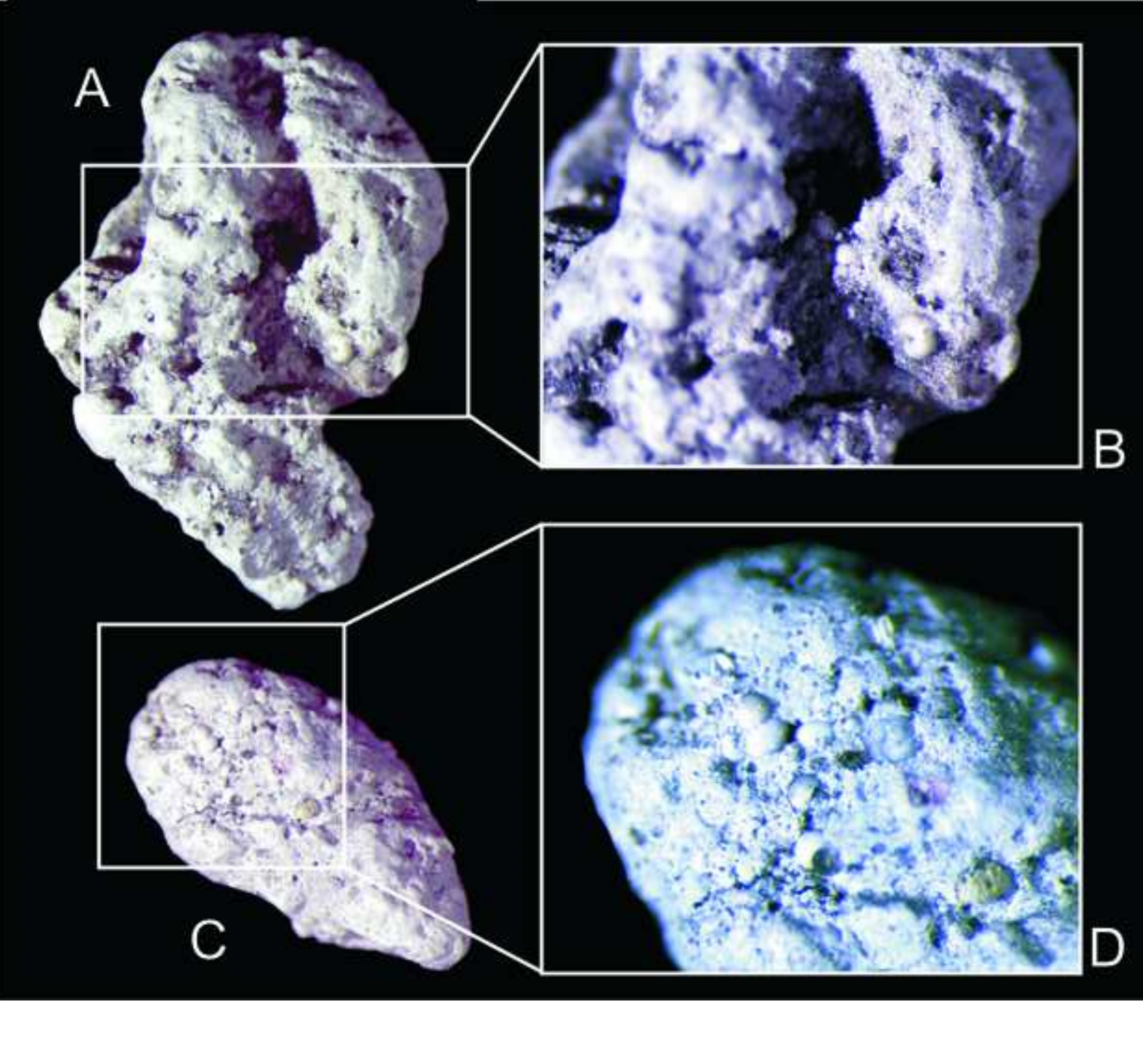

$$
\text { ( }
$$



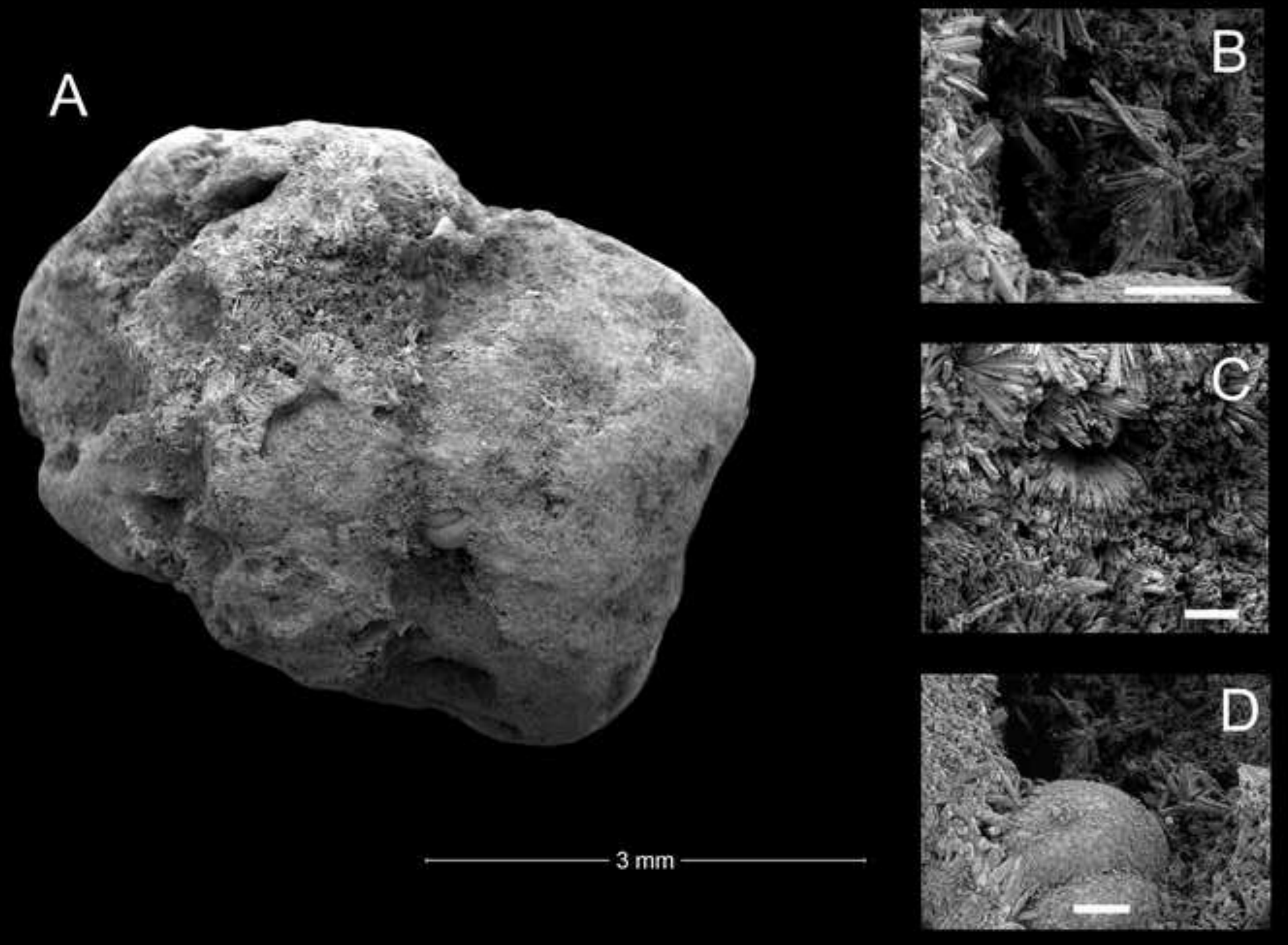


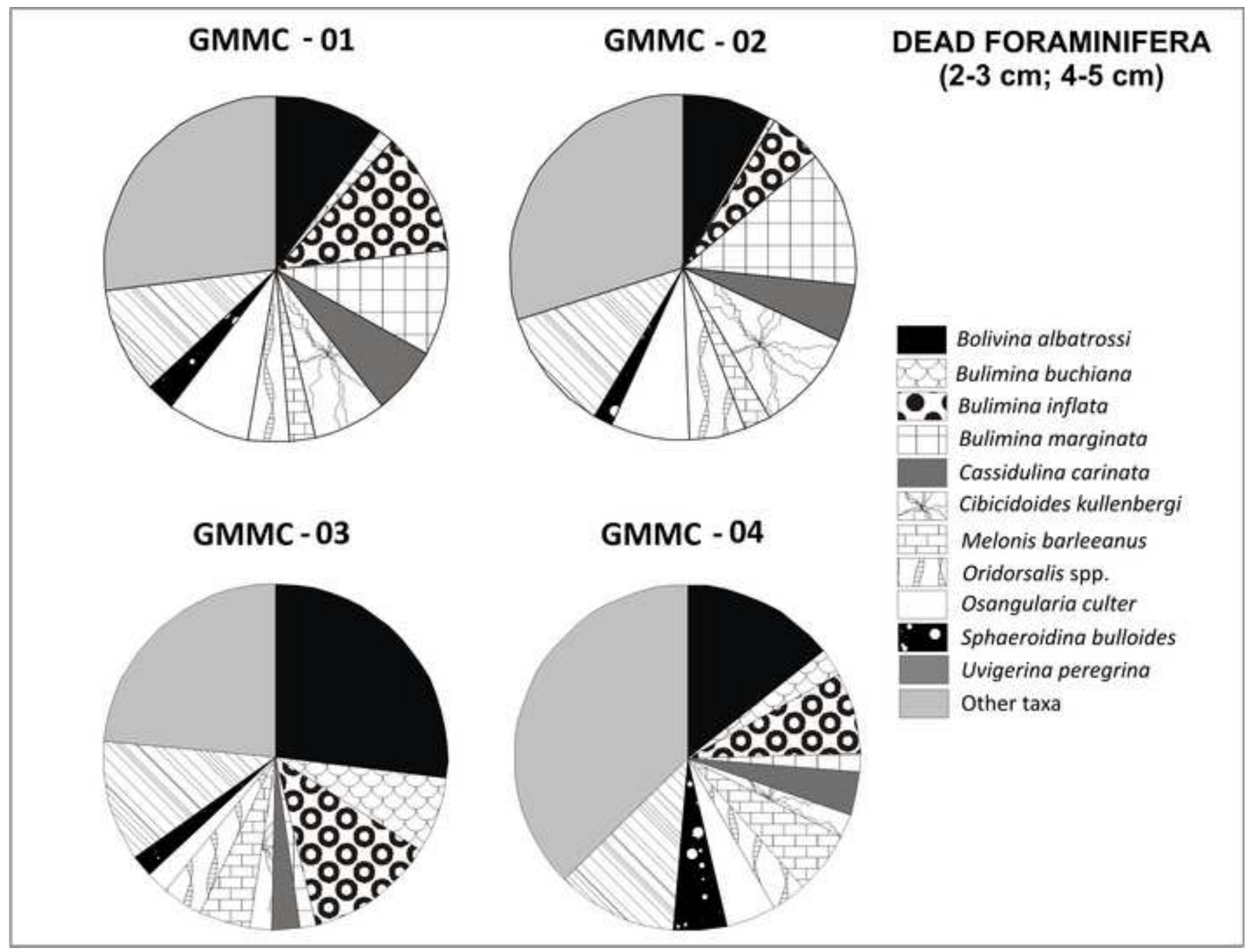




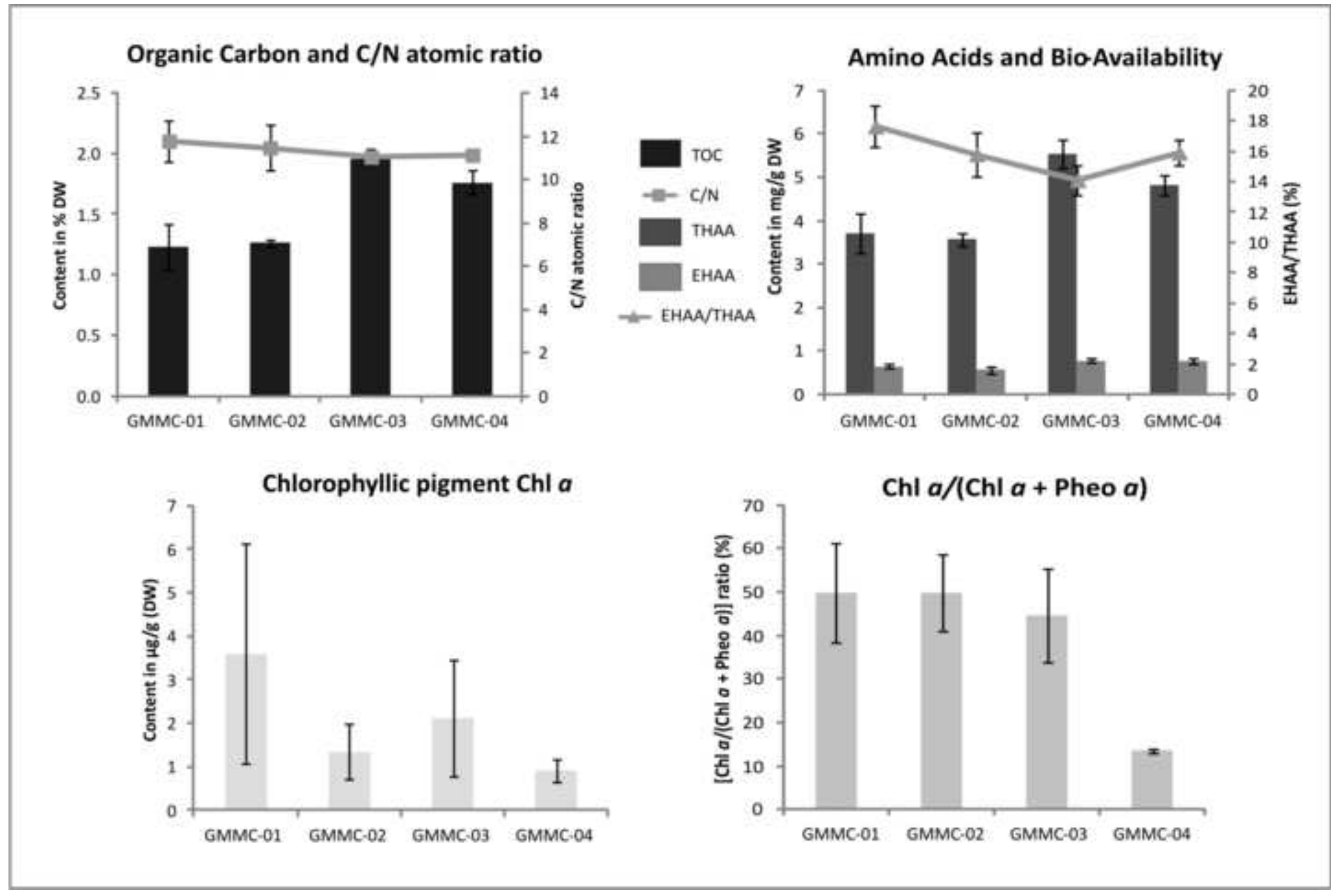




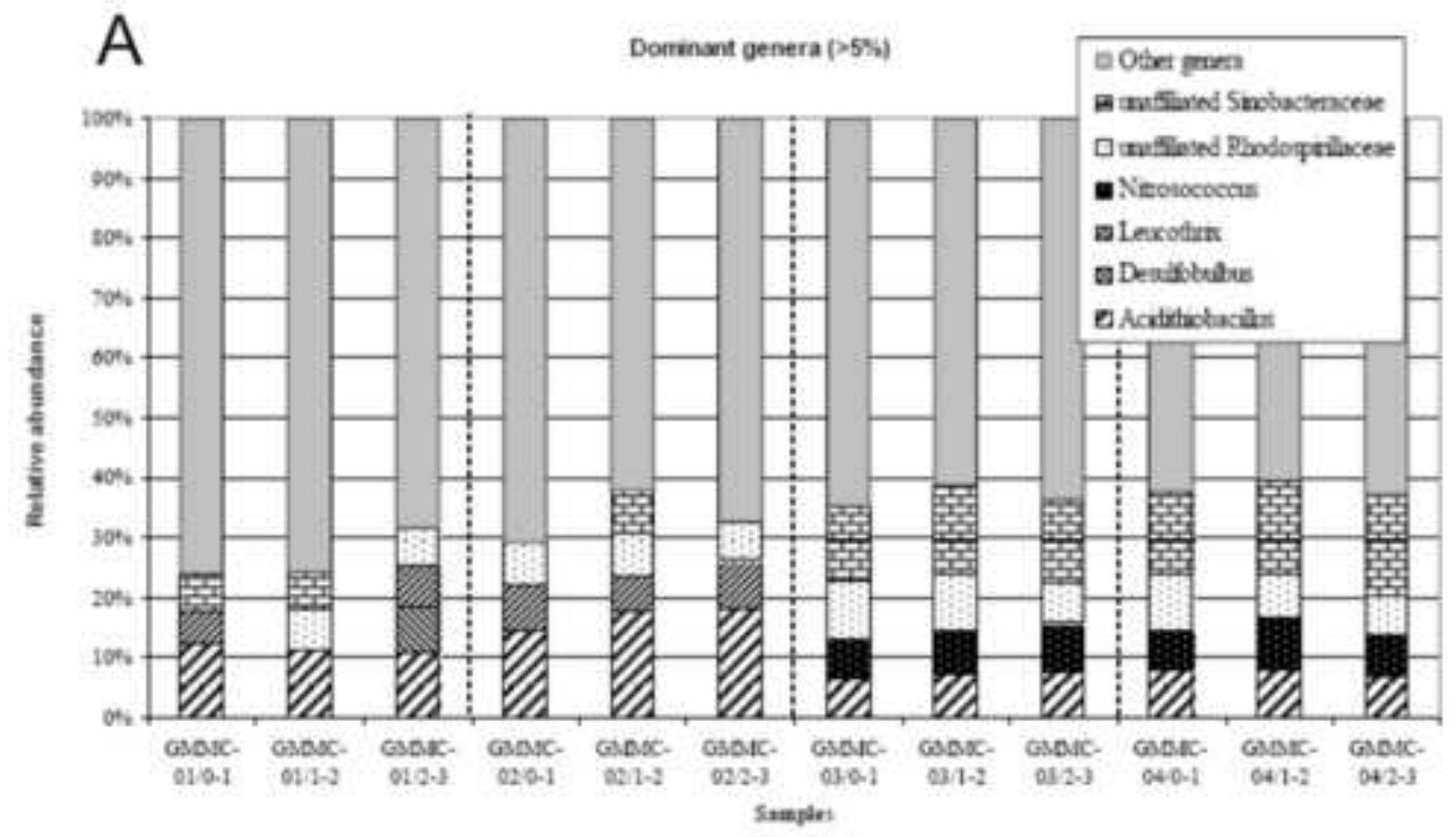

B Sultur-oxıdizing/Sultate-reducing/Methanotrophs tamilies (>1\%)

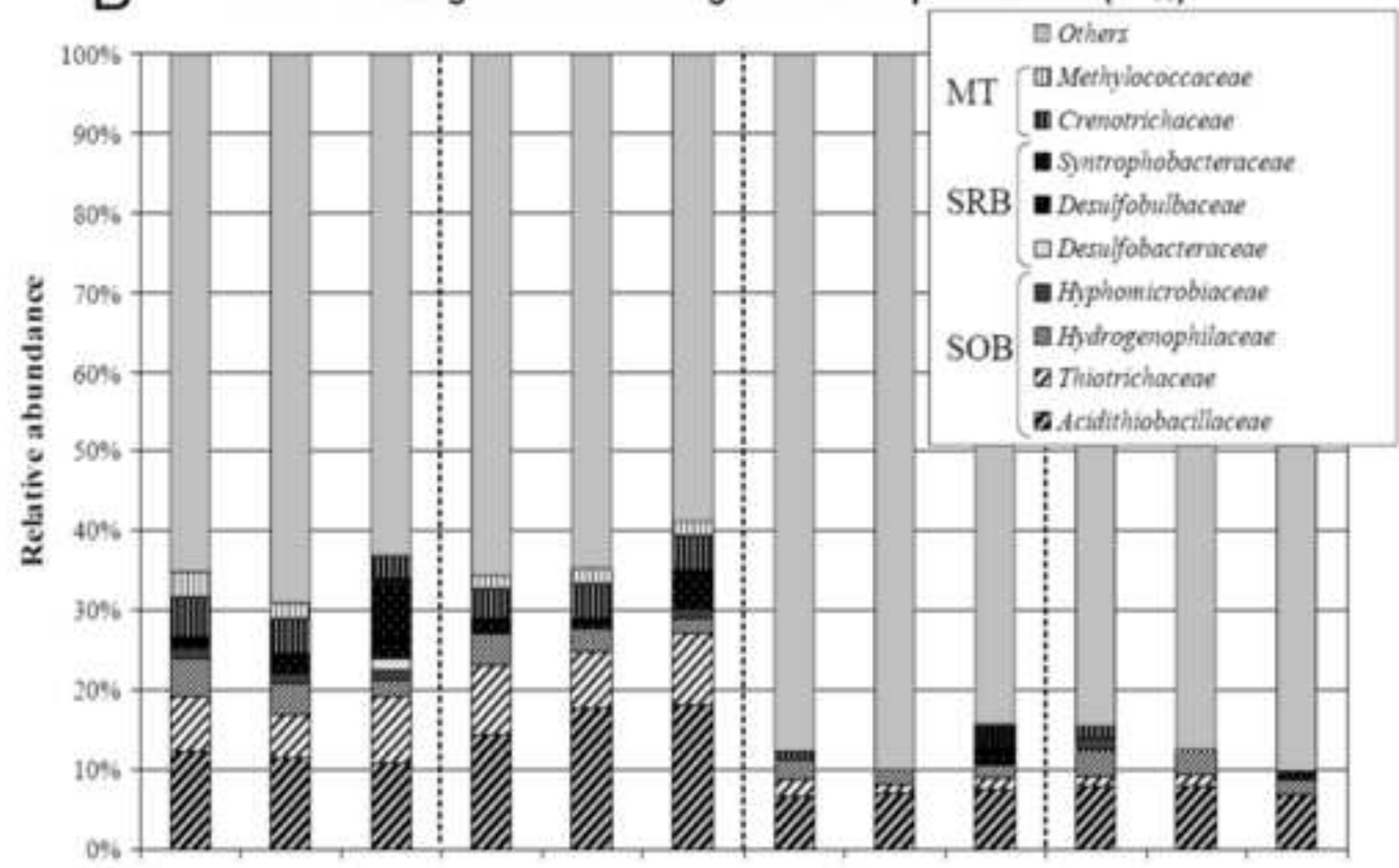

GMMC- GMMC- GMMC GMMC GMMC GMMC GMC- GMMC GMMC- GMC- GMMC-GMMC-

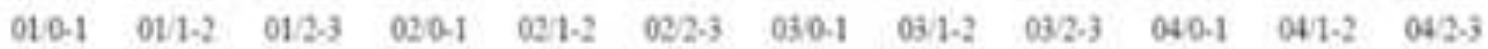




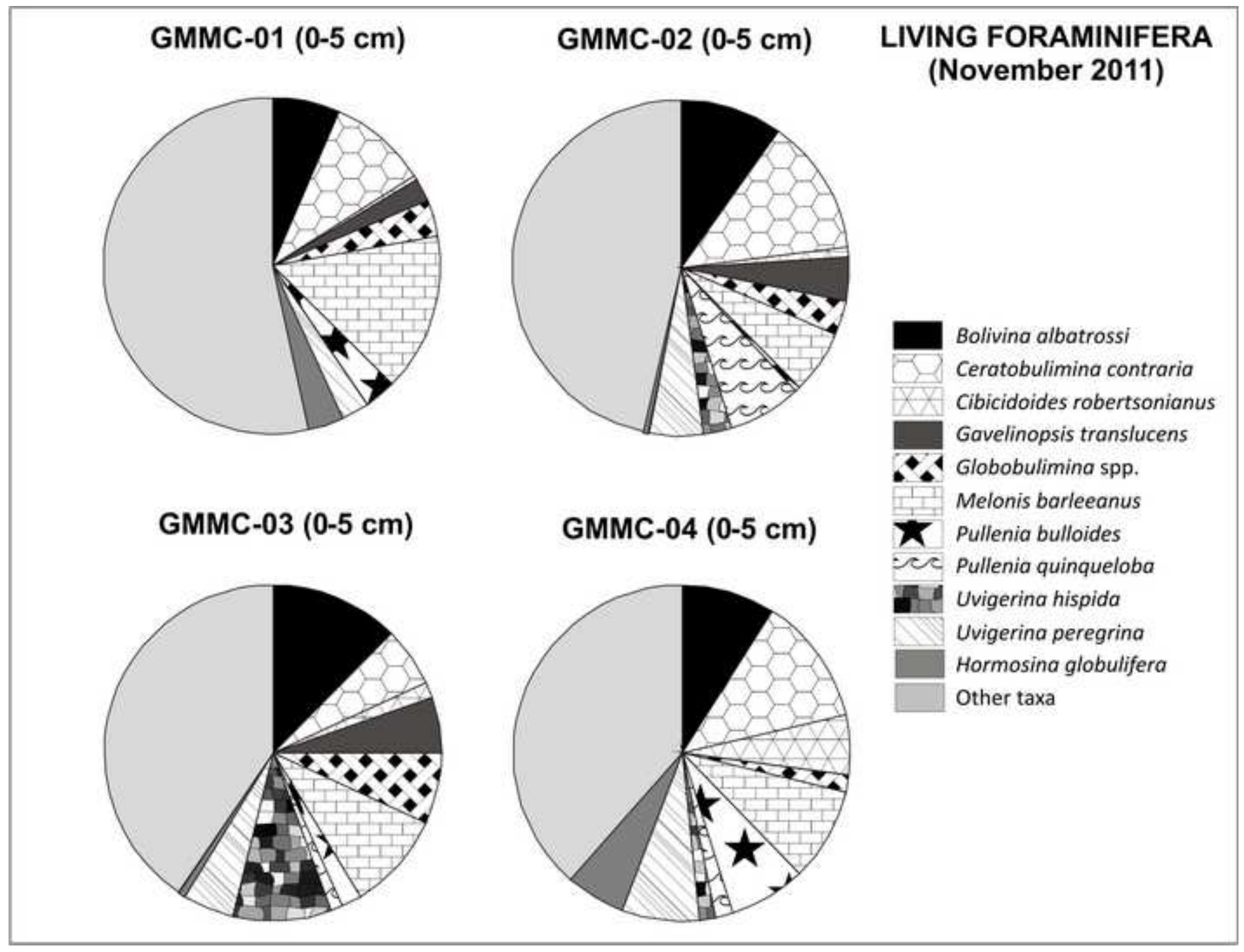




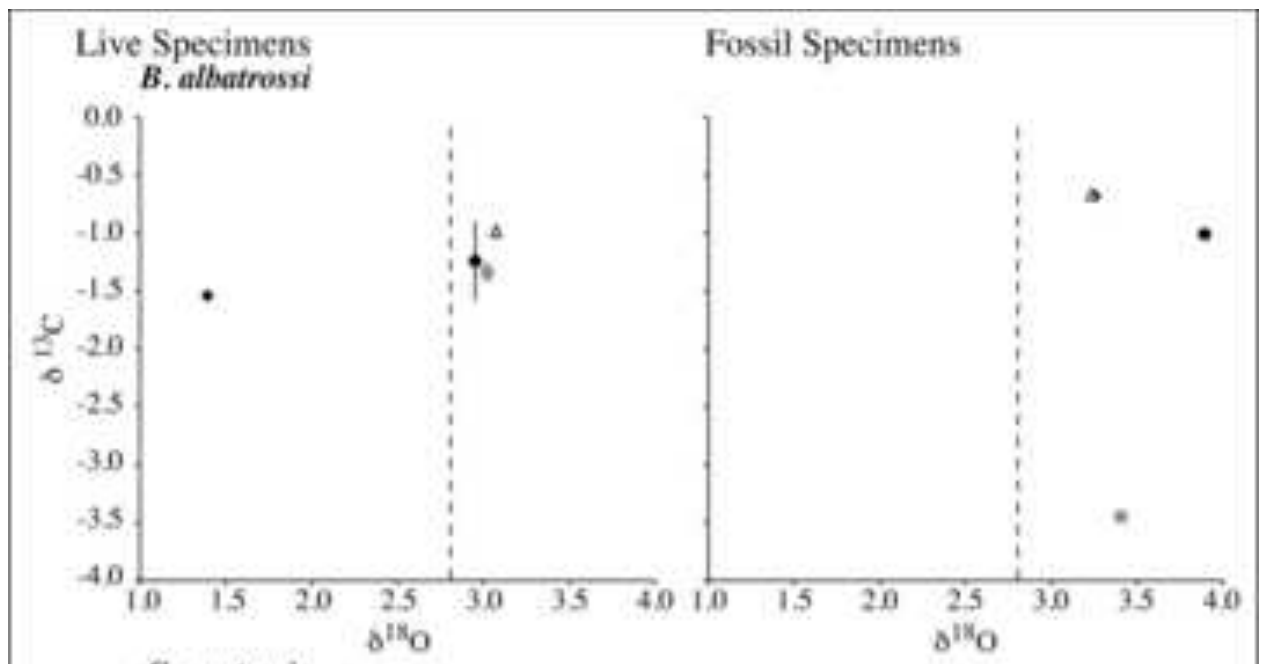

C. contraria
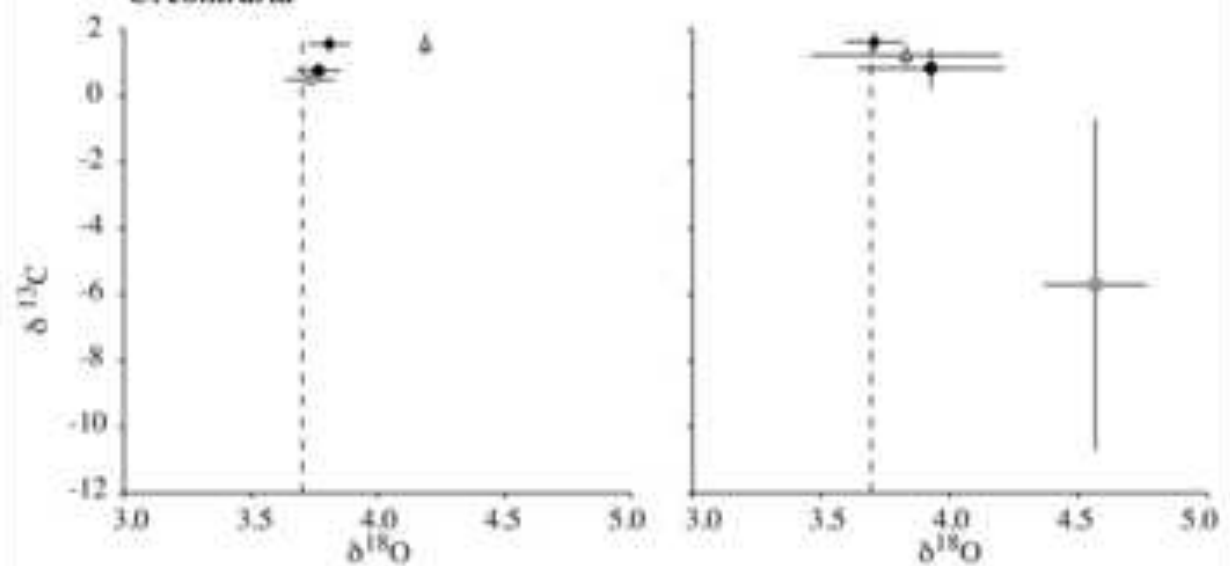

M. barlecamus
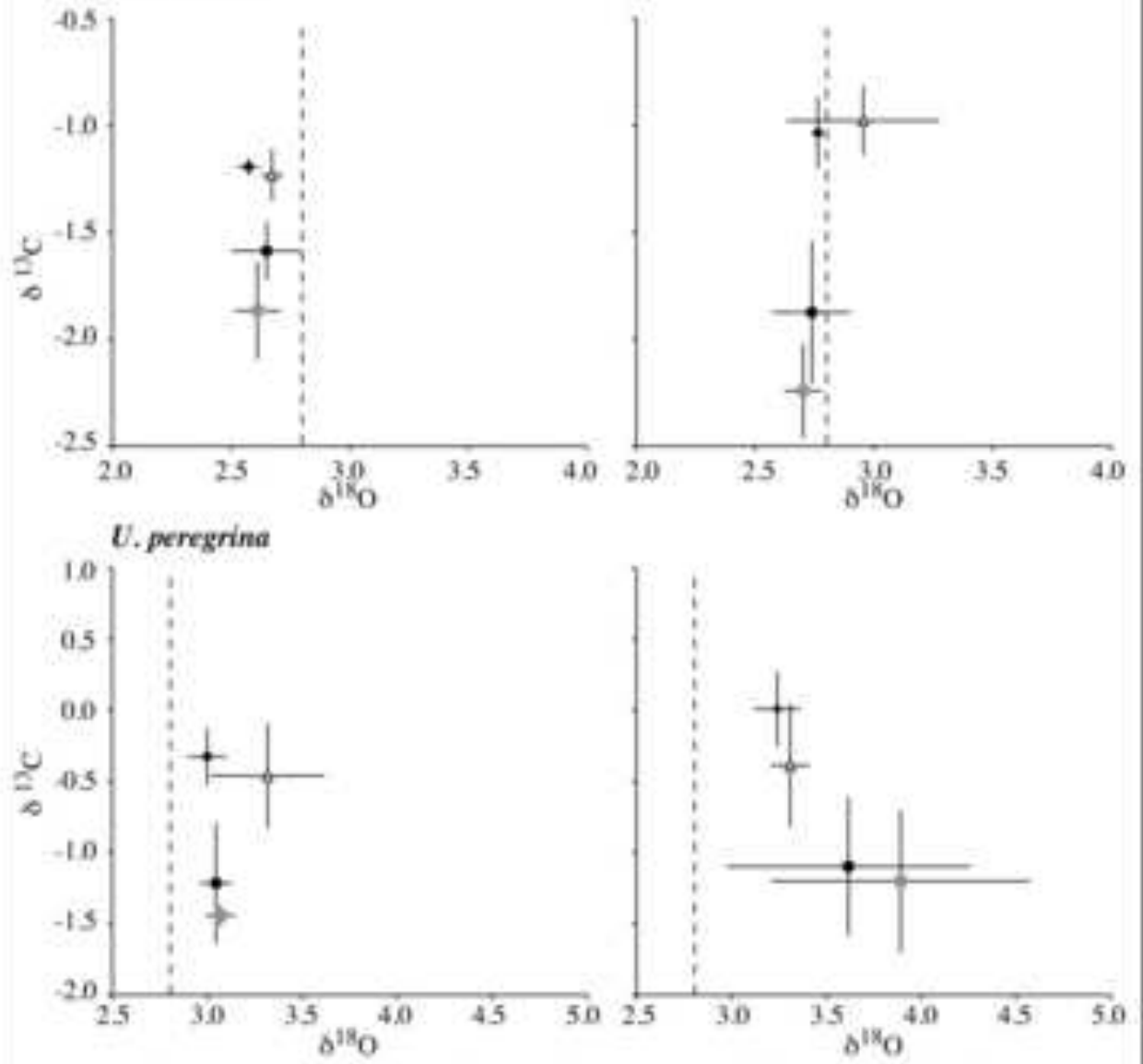

Station: - GMMC-01 = GMMC-02

$\triangle$ GMMC.03 + GMMC.04 


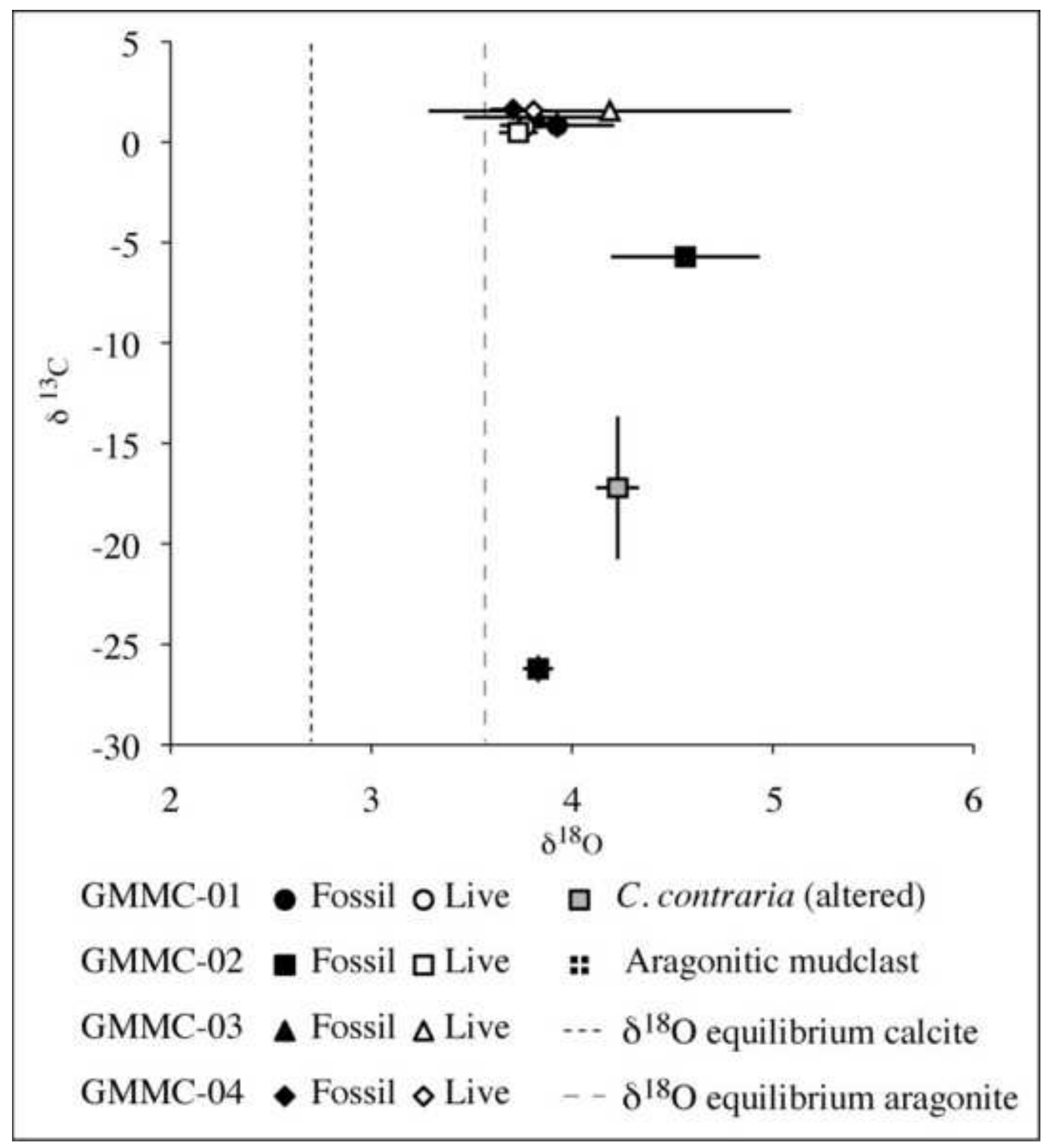

GMMC-01 - Fossil o Live ㄷ. contraria (altered)

GMMC-02 - Fossil aLive :* Aragonitic mudclast GMMC-03 $\Delta$ Fossil $\Delta$ Live $\cdots \delta^{18} \mathrm{O}$ equilibrium calcite GMMC-04 $\bullet$ Fossil $\diamond$ Live $\quad--\delta^{18} \mathrm{O}$ equilibrium aragonite 


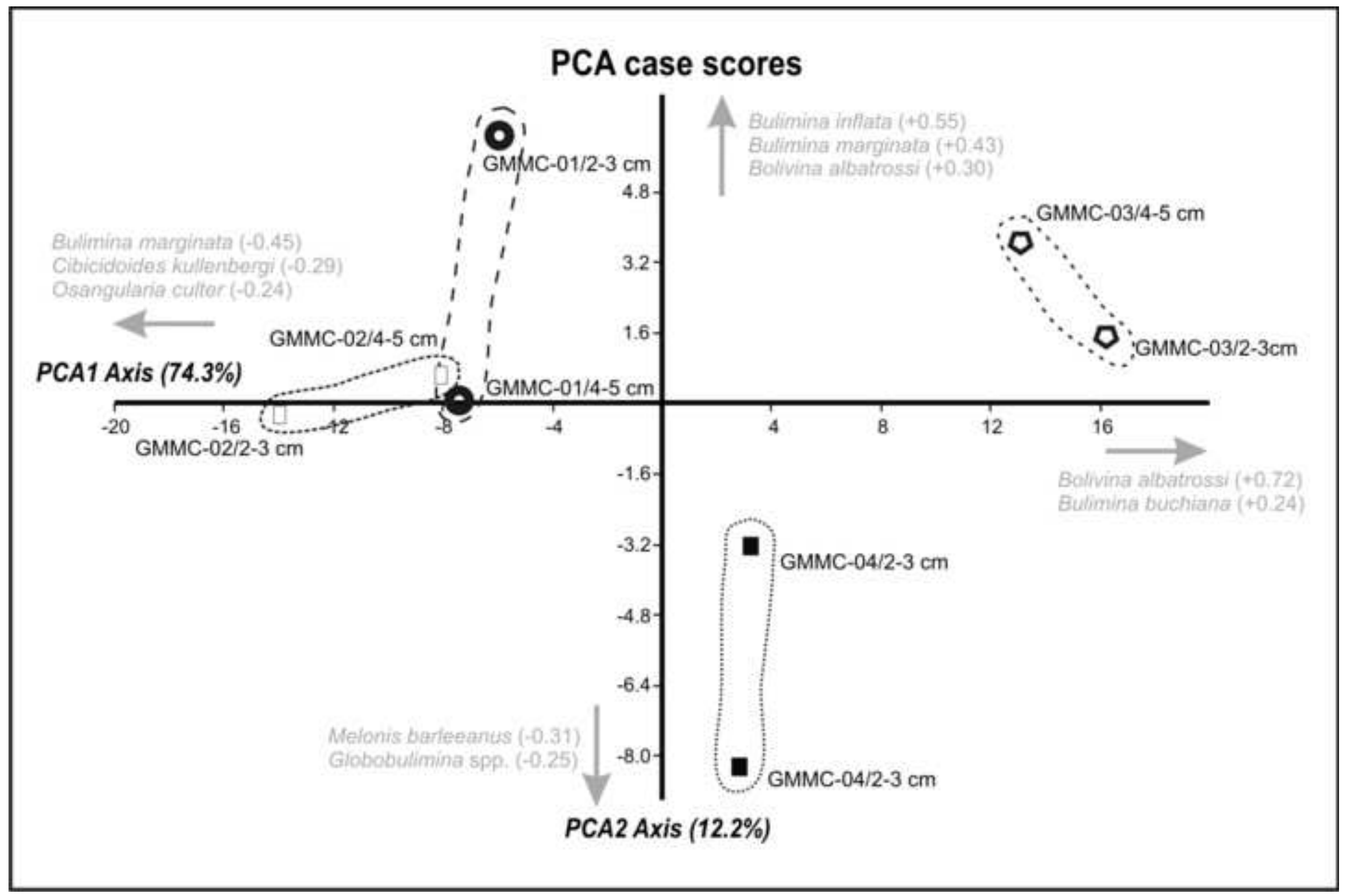

Cibicidoides kullenborgi ( $(-0.29)$

Osangularia cultor $(-0.24)$

\section{PCA1 Axis (74.3\%)}

20

$-4$

Melonis barleteanus $(-0.31)$ Globobulimina spp. $(-0.2 \pm)$

Bulluming intata $(0.0 .55)$

Bolivina albatrossi $(+0.30)$

GMMC-03/4-5 cm

0 